\section{ENVIRONMENTAL}

\section{RESTORATION}

\section{PROGRAM}

\section{Investigation of Groundwater Flow Zones and Contaminant Transport in Solid Waste Storage Area 5 at Oak Ridge National Laboratory, Oak Ridge, Tennessee}

\author{
D. S. Hicks
}

D. K. Solomon

N. D. Farrow 
This report has been reproduced directly from the best available copy.

Available to DOE and DOE contractors from the Office of Scientific and Technical Information, P.O. Box 62, Oak Ridge, TN 37831; prices available from 615-576-8401, FTS 626-8401.

Available to the public from the National Technical Information Service, U.S. Department of Commerce, 5285 Port Royal Rd., Springfield, VA 22161. 


\title{
Investigation of Groundwater Flow Zones and Contaminant Transport in Solid Waste Storage Area 5 at Oak Ridge National Laboratory, Oak Ridge, Tennessee
}

\author{
D. S. Hicks \\ D. K. Solomon \\ N. D. Farrow
}

Date Issued-September 1992

\author{
Prepared by \\ Environmental Sciences Division \\ Oak Ridge National Laboratory \\ ESD Publication 3977
}

Prepared for

U.S. Department of Energy

Office of Environmental Restoration and Waste Management

under budget and reporting code EW 20

OAK RIDGE NATIONAL LABORATORY

Oak Ridge, Tennessee 37831-6285

managed by

MARTIN MARIETTA ENERGY SYSTEMS, INC. for the

U.S. DEPARTMENT OF ENERGY

under contract DE-AC05-84OR21400 


\section{Author Affiliations}

D. S. Hicks, D. K. Solomon, and N. D. Farrow are members of the Environmental Sciences Division of Oak Ridge National Laboratory, Martin Marietta Energy Systems, Inc. 


\section{CONTENTS}

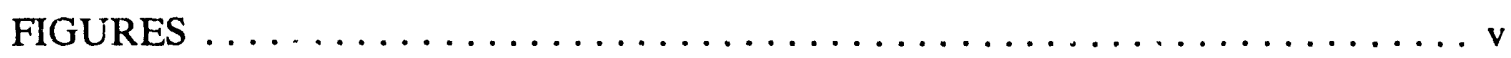

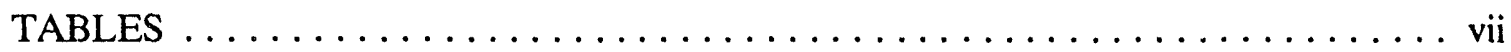

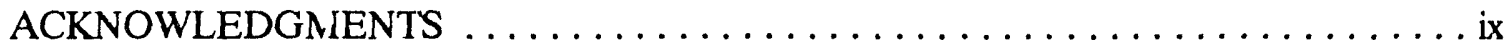

EXECUTIVE SUMMARY $\ldots \ldots \ldots \ldots \ldots \ldots \ldots \ldots \ldots \ldots \ldots \ldots \ldots \ldots \ldots \ldots \ldots$

1. INTRODUCTION $\ldots \ldots \ldots \ldots \ldots \ldots \ldots \ldots \ldots \ldots \ldots \ldots \ldots \ldots \ldots \ldots$

2. BACKGROUND OF STUDY AREA $\ldots \ldots \ldots \ldots \ldots \ldots \ldots \ldots \ldots \ldots \ldots \ldots \ldots \ldots \ldots$

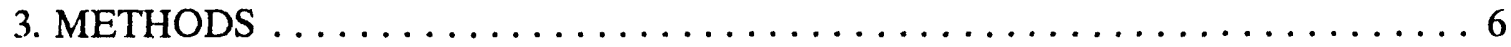

3.1 BOREHOLE D'KILLING $\ldots \ldots \ldots \ldots \ldots \ldots \ldots \ldots \ldots \ldots \ldots \ldots \ldots \ldots \ldots$

3.2 GROUNDWATER SAMPLE COLLECTION $\ldots \ldots \ldots \ldots \ldots \ldots \ldots 6$

3.3 SAMPLE ANALYSIS $\ldots \ldots \ldots \ldots \ldots \ldots \ldots \ldots \ldots \ldots, \ldots \ldots \ldots$

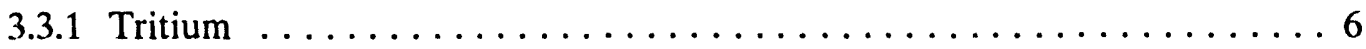

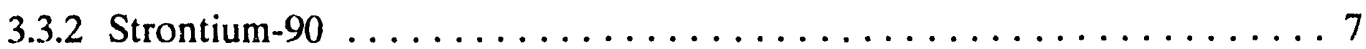

3.4 ELECTROMAGNETIC BOREHOLE FLOWMETER $\ldots \ldots \ldots \ldots \ldots 7$

3.5 BOREHOLE DILUTION TEST $\ldots \ldots \ldots \ldots \ldots \ldots \ldots \ldots \ldots \ldots$

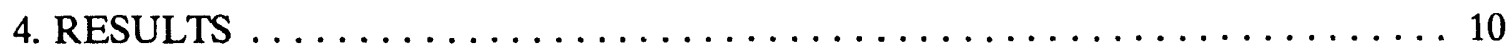

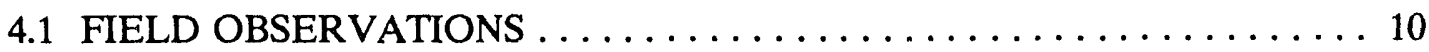

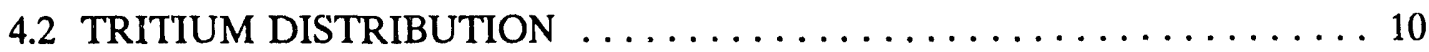

4.3 ELECTROMAGNETIC BOREHOLE FLOWMETER $\ldots \ldots \ldots \ldots \ldots \ldots$

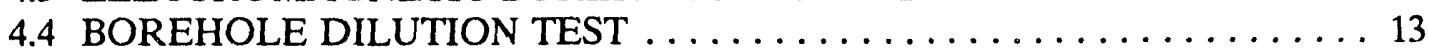

4.5 COMPARISON OF BOREHOLE DILUTION RESULTS WITH

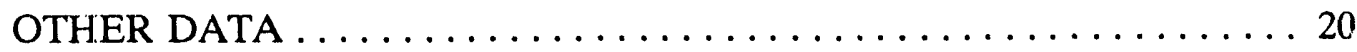

4.6 SEASONAL VARIABILITY OF CONTAMINANT DISCHARGE $\ldots \ldots 22$

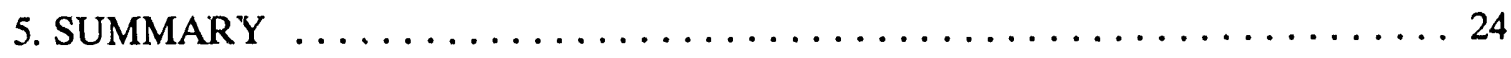

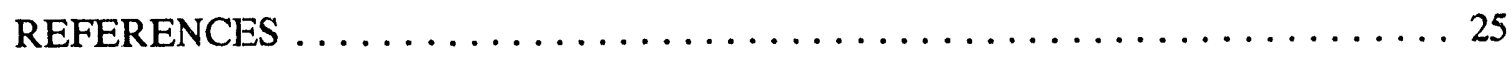




\section{FIGURES}

Figure

Page

1

2

Map of study area in SWSA $5 \ldots \ldots \ldots \ldots \ldots \ldots \ldots \ldots$

Distribution of ${ }^{3} \mathrm{H}$ activity $(\mu \mathrm{Ci} / \mathrm{L})$ in groundwater and soil core samples from the southeastern edge of SWSA $5 \ldots \ldots \ldots \ldots$

Vertical distribution of ${ }^{3} \mathrm{H}$ at Site $3 \ldots \ldots \ldots \ldots \ldots \ldots$

Distribution of ${ }^{90} \mathrm{Sr}$ activity $(\mathrm{nCi} / \mathrm{L})$ in groundwater samples $\ldots \ldots \ldots 5$

Diagram of borehole dilution test setup $\ldots \ldots \ldots \ldots \ldots \ldots$

Results from borehole flowmeter survey conducted during

ambient conditions

Results from borchole flowmeter survey conducted while maintaining a constant head by injection

Results from borehole flowmeter survey conducted on 2-in.-diam well while maintaining a constant head by injection $\ldots \ldots \ldots \ldots \ldots$

Typical response of specific conductance within an interval during a borehole dilution test $\ldots \ldots \ldots \ldots \ldots \ldots \ldots \ldots \ldots$

Borehole dilution test results from the 7 - to 10.25 - $\mathrm{ft}$ interval $\ldots \ldots \ldots 15$

Borehole dilution test results from the 10 - to 13.25 -ft interval $\ldots \ldots \ldots 16$

Borehole dilution test results from the 12 - to 15.25 - $\mathrm{ft}$ interval $\ldots \ldots \ldots 16$

Borehole dilution test results from the $13-$ to 16.25 -ft interval $\ldots \ldots \ldots 17$

Borehole dilution test results from the 15 - to 18.25 - $\mathrm{ft}$ interval $\ldots \ldots \ldots 17$

Borchole dilution test results from the 18 - to 21.25 - $\mathrm{ft}$ interval $\ldots \ldots \ldots 18$

Borehole dilution test results from the 20 - to 23.25 - $\mathrm{ft}$ interval $\ldots \ldots \ldots 18$

Borehole flowmeter and borehole dilution results $\ldots \ldots \ldots \ldots$

Tritium mass flow in Melton Branch and Melton Branch Tributary ... 21 
19 Cross section of study area relating specific discharge values

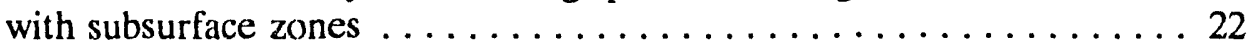

20 Temporal activity of ${ }^{3} \mathrm{H}$ in the seep and Well $5 \mathrm{D} \ldots \ldots \ldots \ldots 23$

21 Temporal activity of ${ }^{90} \mathrm{Sr}$ in the seep and Well $5 \mathrm{D} \ldots \ldots \ldots \ldots$ 


\section{TABLES}

Table

Page

1 Tritium activities in extracted water from core samples $\ldots \ldots \ldots \ldots 11$

2 Estimated specific discharge in each interval

computed from borehole dilution tests $\ldots \ldots \ldots \ldots \ldots \ldots$ 


\section{ACKNOWLEDGMENTS}

The authors appreciate John Dunning with the Engineering Laboratory of Tennessee Valley Authority for providing the instrumentation and collection of electromagnetic borehole flowmeter measurements.

The authors also wish to thank G. K. Moore and P. M. Jardine for their constructive review of the report. 


\section{EXECUTIVE SUMMARY}

An understanding of subsurface transport processes is essential to produce realistic predictions of future contaminant discharge from Solid Waste Storage Areas (S'NSAs) at Oak Ridge National Laboratory (ORNL). In addition, locating groundwater flow zones (permeable pathways) and determining the relative contributions of primary vs secondary contaminant sources are critical to the proper selection and evaluation of remedial actions. Because groundwater discharge from SWSA 5 contributes significant amounts of ${ }^{3} \mathrm{H}$ and ${ }^{90} \mathrm{Sr}$ to the White Oak Creek watershed, an area on the southeastern edge of SWSA 5 was chosen for an investigation aimed at understanding and characterizing the subsurface movement of contaminants. Preliminary data collected in 1991 indicated that the vertical distribution of ${ }^{3} \mathrm{H}(0.02$ to $279 \mu \mathrm{Ci} / \mathrm{L})$ observed over the sampled interval ( 0 to $10 \mathrm{ft}$ deep) may be a result of upward diffusion from a hydraulically dominant fracture (or fractured zone) below the sampled interval. The investigation continued this year (1992) with the primary objective of defining where the most permeable zones exist in the subsurface and how they relate to the vertical extent of ${ }^{3} \mathrm{H}$.

An open borehole was drilled on the southeastern edge of SWSA 5 through the upper zones of soil and saprolite and then through interbedded shales and limestones to a depth of about $26 \mathrm{ft}$. Two methods were used to determine permeable zones within the borehole. The first was a survey of changes in vertical flows over the depth of the borehole, using the electromagnetic (EM) borehole flowmeter developed by Tennessee Valley Authority. The second was the borehole dilution (point-dilution) method, which provided estimates of groundwater flows in different packed-off intervals within the borehole. The results from the two methods correspond quite well. The EM borehole flowmeter results suggest that the zone from 15 to $18 \mathrm{ft}$ is the most permeable in the borehole, and the borehole dilution test results indicate that the most permeable zone is from 13 to $16.25 \mathrm{ft}$. The specific discharge value for this interval as determined by the borehole dilution tests was $1.46 \mathrm{ft} /$ day (162 m/year), which was 3.5 to 5 times greater than most of the other intervals within the borehole. Because groundwater streamlines converge towards an open borehole, the true specific discharge in the formation is probably less than that measured in the borehole from using the borehole dilution method. A comparison of independent data (stream discharge and ${ }^{3} \mathrm{H}$ mass flow from a nearby tritiated seep) suggests that the calculated specific discharge values are reasonable and are likely to be correct within a factor of 4 .

In addition to determining groundwater flow zones in this area of SWSA 5, samples were collected monthly from a nearby well and seep (where tritiated groundwater discharges) to determine seasonal variability in the transport of ${ }^{3} \mathrm{H}$ and ${ }^{90} \mathrm{Sr}$ from the study area. Tritium and ${ }^{90} \mathrm{Sr}$ activities in the wells and seep samples varied over the sampling period from April 1991 to June 1992. Variations in hydrologic condition; (seasons) appear to govern both ${ }^{3} \mathrm{H}$ and ${ }^{90} \mathrm{Sr}$ activities in the seep, with activities being lowest during the wetter (winter) season and higher in the late spring and summer when conditions are drier. 
For the purposes of determining the ${ }^{3} \mathrm{H}$ activities at depths, core samples (primarily shale samples) from the borehole drilling were analyzed for ${ }^{3} \mathrm{H}$. The results suggest that the activity generally decreases with depth below $10 \mathrm{ft}$. However, because of the drilling method (drilling fluid diluted ${ }^{3} \mathrm{H}$ activities in the core samples) the results from the cores are tentative. To better understand the subsurface transport and sources of ${ }^{3} \mathrm{H}$ in this area of SWSA 5, it will be necessary to determine the ${ }^{3} \mathrm{H}$ activities at greater depths and relate them with the most hydrologically active zones. As the study continues during 1993 , reliable ${ }^{3} \mathrm{H}$ and ${ }^{90} \mathrm{Sr}$ activities will be determined in the different subsurface zones by using a multilevel sampling device installed in the borehole. A comparison of the ${ }^{3} \mathrm{H}$ activity in the most hydraulically active regions with the activity in the surrounding matrix can be used to help determine whether or not primary sources are still active and whether contaminant release from SWSA 5 to the stream will increase or decrease in future years. 


\section{INTRODUCTION}

The contaminant transport (primarily ${ }^{3} \mathrm{H}$ and ${ }^{90} \mathrm{Sr}$ ) from Solid Waste Storage Area (SWSA) 5 comprises a large amount of the total within the White Oak Creek watershed. Contaminants within SWSA 5 are leached from primary sources (waste burial trenches) and migrate through the subsurface. Secondary sources have likely developed downgradient as contaminants have moved through the subsurface along permeable pathways and then have diffused into low-permeability regions. Secondary sources can become active as primary sources are leached, removed, or isolated, and contaminants begin to diffuse out of lowpermeability regions back into permeable pathways. Locating groundwater flow zones (permeable pathways) and determining the relative contributions of primary vs secondary sources are important in the proper selection and evaluation of remedial actions. Remedial actions aimed at individual trenches or areas will not be effective at reducing contaminant discharge if secondary sources contain and release a greater amount of contaminants. An understanding of subsurface transport processes is essential to produce realistic predictions of future contaminant discharge and evaluations of remedial action effectiveness.

A preliminary investigation was initiated in 1991 to characterize the subsurface movement of contaminants (primarily ${ }^{3} \mathrm{H}$ ) from SWSA 5 with an emphasis on the effects of matrix diffusion, the diffusive exchange of ions between regions of high and low permeability (Wickliff et al. 1991). Observed ${ }^{3} \mathrm{H}$ and ${ }^{90} \mathrm{Sr}$ values were used to formulate a working hypothesis of contaminant transport, the role of matrix diffusion, and the existence of primary and secondary sources in SWSA 5. The vertical profile of ${ }^{3} \mathrm{H}$ may be a result of upward diffusion from a hydraulically dominant fracture (or fracture zone) coupled with a small amount of lateral advective transport within the matrix. The occurrence of a hydraulically dominant fracture of high ${ }^{3} \mathrm{H}$ activity would suggest that there is still an upgradient source supplying ${ }^{3} \mathrm{H}$ to the subsurface flow system and that the contaminant release from SWSA 5 to the stream will continue to increase until that source diminishes in strength. Because this hypothesis is tentative and additional data are needed to completely interpret the results, the investigation continued this year (1992) with the objective of defining where the most permeable zones exist in the subsurface and how they relate to the vertical extent of ${ }^{3} \mathrm{H}$. In the future a comparison of the ${ }^{3} \mathrm{H}$ activity in the most hydrologically active regions with the ${ }^{3} \mathrm{H}$ activity in the matrix will be used to help determine whether or not primary sources are still active. 


\section{BACKGROUND OF STUDY SITE}

As part of Waste Area Grouping (WAG) 5, most of SWSA 5 consists of moderately sloping, grass-covered hillsides that drain to White Oak Creek (WOC) to the west and to Melton Branch and the Melton Branch Tributary to the south and east (Fig. 1). SWSA 5 is underlain by the Conasauga Group, consisting of shaley limestones and shales striking generally east-west and dipping to the south. Trenches were often located at right angles to the bedding strike to minimize collapse of the trench walls. As a result, most of the trenches are located parallel to the slope.

In 1991 an area on the southeastern edge of SWSA 5, where a known contaminant plume (primarily ${ }^{3} \mathrm{H}$ ) exists, was selected for a preliminary investigation to gain understanding of processes (particularly matrix diffusion) that may be affecting contaminant transport from primary waste sources to streams (Wickliff et al. 1991). Contaminated groundwater from this area discharges at a seep in the bank of iMelton Branch Tributary (Fig. 1). To define the vertical profile and extent of ${ }^{3} \mathrm{H}$ and ${ }^{90} \mathrm{Sr}$, soil core and groundwater samples were collected from various depths at three locations (Fig. 1). One location, Site 5, is just below the trenches on the very edge of the grassy burial ground. Site 2 is downgradient in a wooded area, and Site 3 is on the floodplain of Melton Branch Tributary approximately $10 \mathrm{~m} \mathrm{(33 \textrm {ft } )}$ from the seep.

Wickliff et al. (1991) found that ${ }^{3} \mathrm{H}$ activities in the groundwater and soil core samples increase with depth and ranged from 0.02 to $279 \mu \mathrm{Ci} / \mathrm{L}$ (Fig. 2). The vertical distribution of ${ }^{3} \mathrm{H}$ was very smooth (Fig. 3 ), unlike what might be expected in a fractured and heterogeneous environment, and suggests that diffusion is an important transport mechanism in SWSA 5. In addition, there was little difference between ${ }^{3} \mathrm{H}$ activities in the groundwater samples and activities in pore water extracted from soil cores, which suggests that diffusion, rather than advection through hydraulically active fractures, dominates contaminant transport over the intervals (0 to about $10 \mathrm{ft}$ ) sampled in the study by Wickliff et al. (1991).

Wickliff et al. found that the peak ${ }^{90} \mathrm{Sr}$ activities (Fig. 4) did not coincide with peak ${ }^{3} \mathrm{H}$ activities, which may indicate that ${ }^{90} \mathrm{Sr}$ and ${ }^{3} \mathrm{H}$ come from physically distinct primary sources (i.e., the ${ }^{90} \mathrm{Sr}$ source may be shallow in nearby trenches, whereas the ${ }^{3} \mathrm{H}$ source may be more distant and at greater depth). The observed ${ }^{90} \mathrm{Sr}$ distribution may be a result of a small amount of advective transport within the sampled interval. 


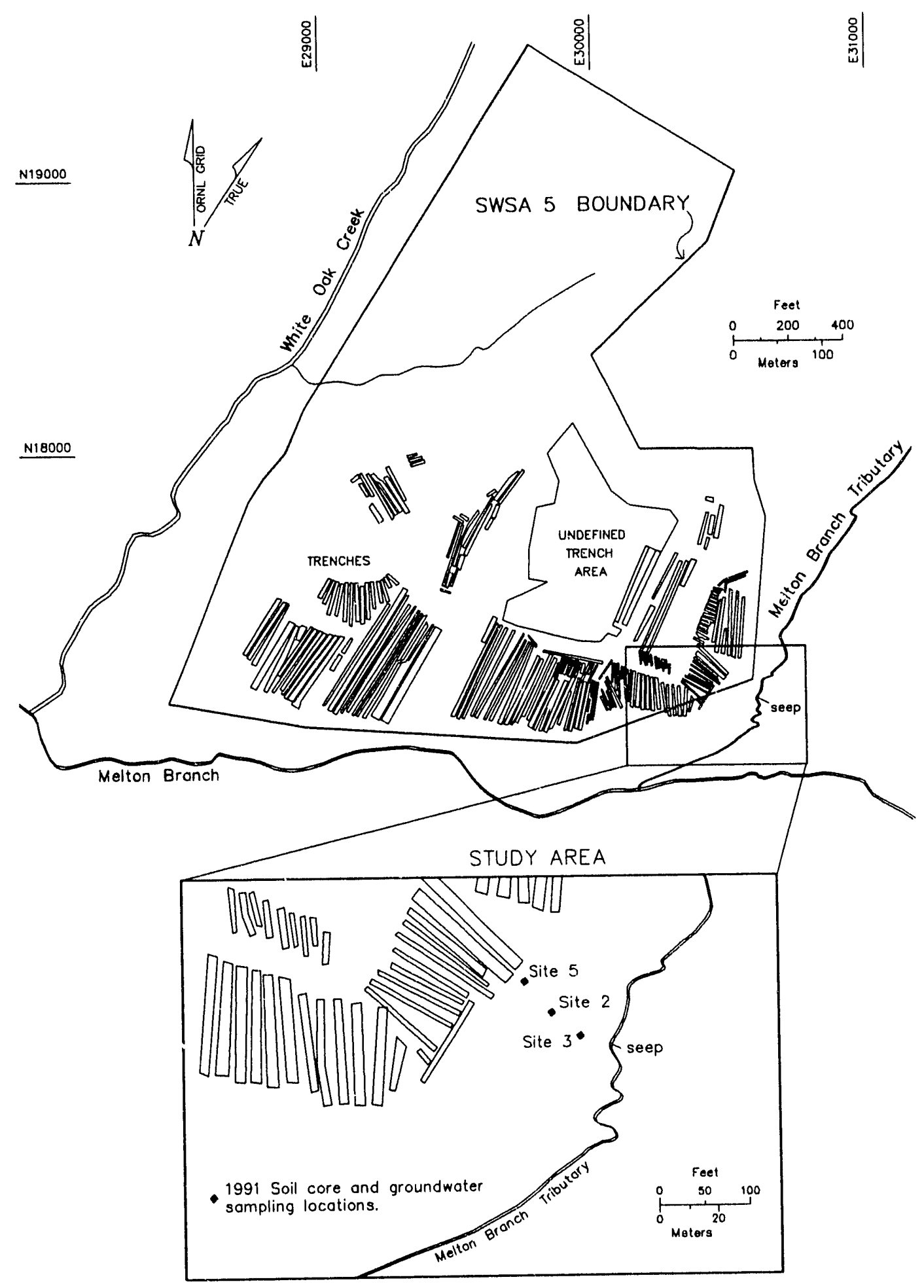

Fig. 1. Map of study area in SWSA 5. 


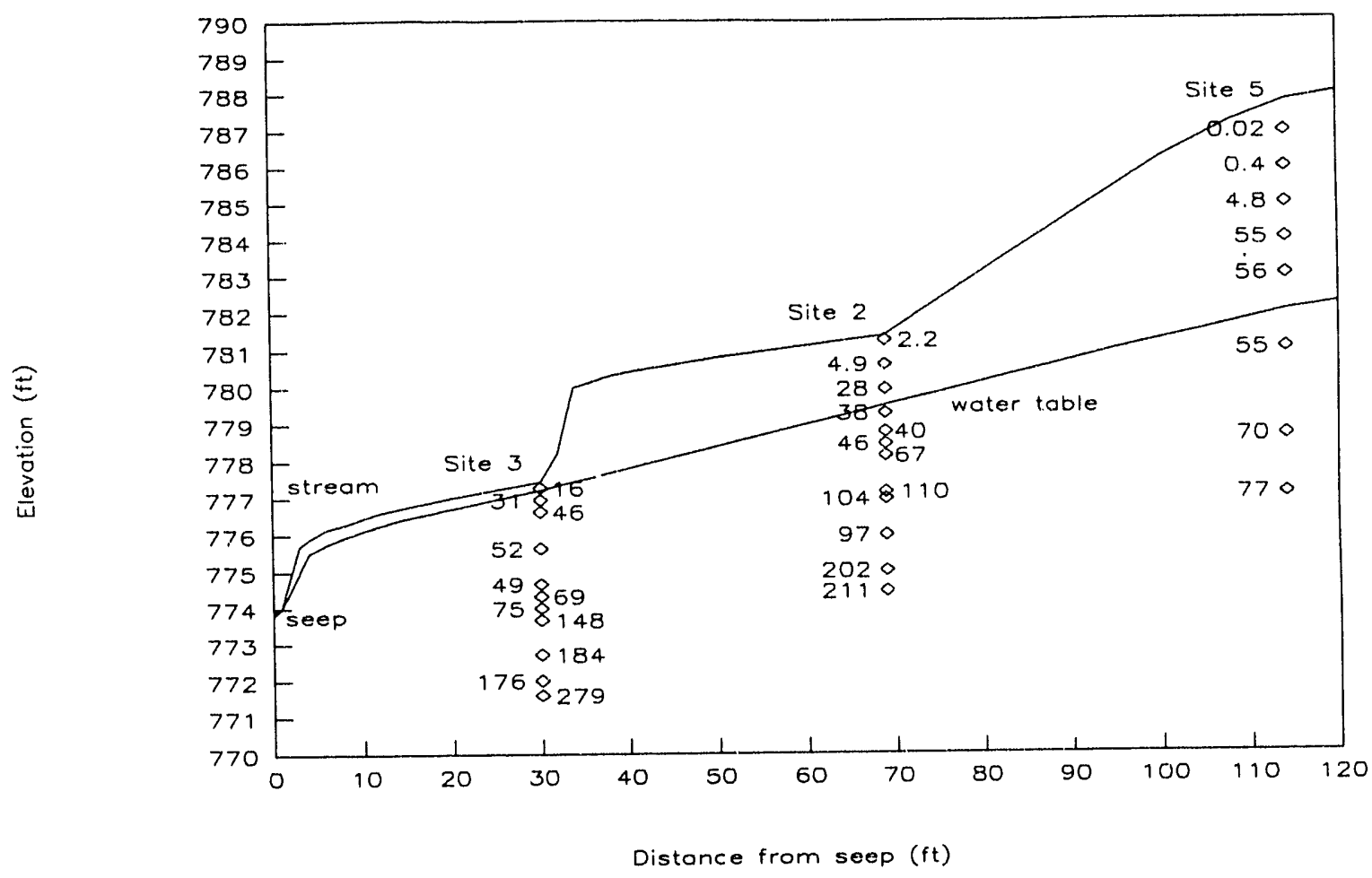

Fig. 2. Distribution of ${ }^{3} \mathrm{H}$ activity $(\mu \mathrm{Ci} / \mathrm{L})$ in groundwater and soil core samples from the southeastern edge of SWSA 5.

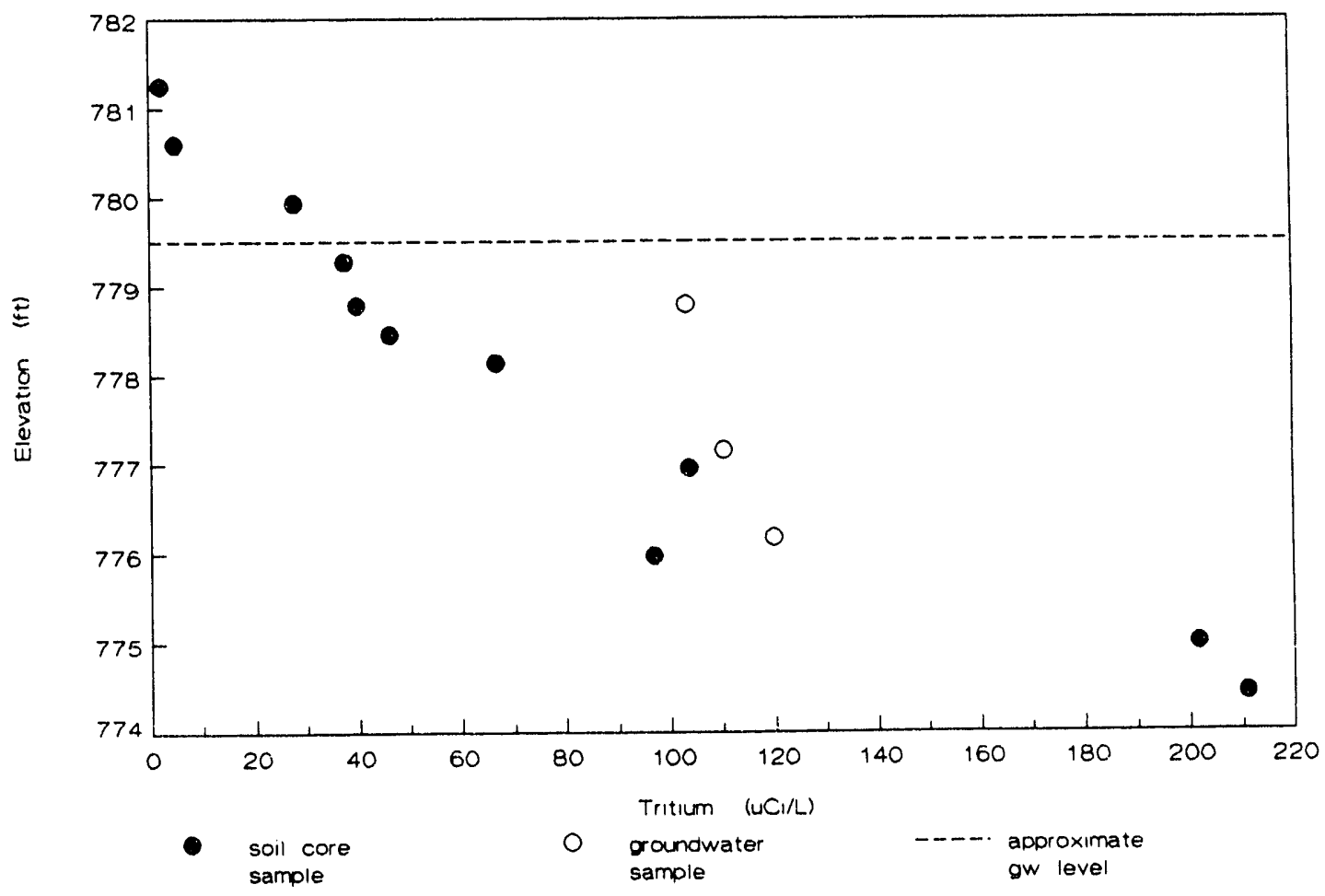

Fig. 3. Vertical distribution of ${ }^{3} \mathrm{H}$ at Site 3 . 


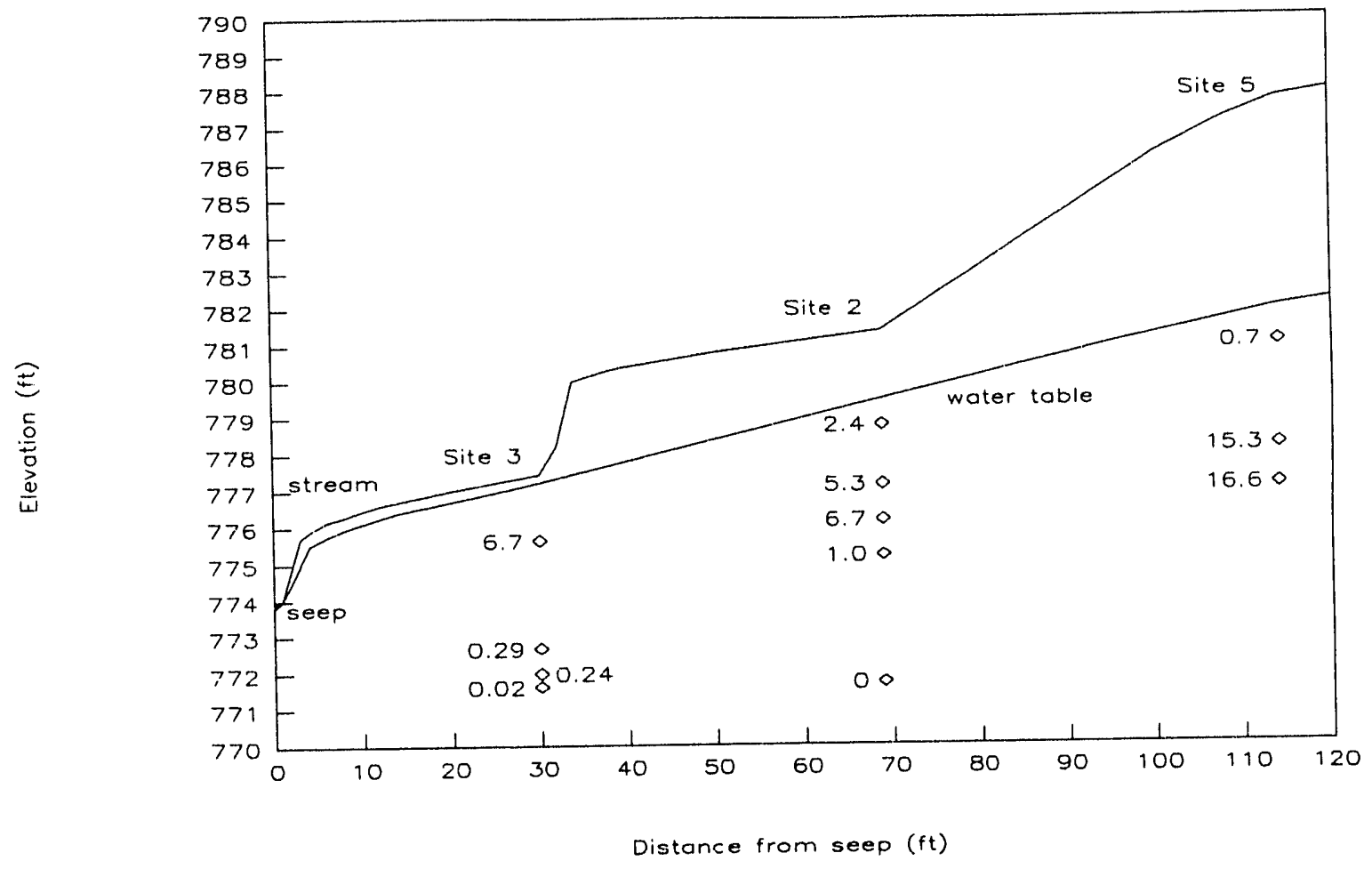

Fig. 4. Distribution of ${ }^{90} \mathrm{Sr}$ activity (nCi/L) in groundwater samples. 


\section{METHODS}

Activities during 1992 consisted of drilling new boreholes, sampling and analyzing groundwater, and performing electromagnetic borehole flowmeter and borehole dilution tests. The flowmeter and dilution tests were designed to delineate permeability zones and to determine the vertical distribution of groundwater flow rates, respectively.

\subsection{BOREHOLE DRILLING}

Drive-point wells were used in 1991, but their use limited collection of data to the soil and upper saprolite zones (about $10 \mathrm{ft}$ deep). To collect samples from deeper depths and to locate zones that may be more hydrologically active, a borehole was drilled to a depth of almost $8 \mathrm{~m}(26 \mathrm{ft}$ ) at Site 2 (Fig. 1). The upper $2 \mathrm{~m}$ of soil and saprolite were augered, and a 4-in. drive casing was pushed in place before the remainder of the hole was drilled. A double-tube core barrel was used with tap water in wet rotary coring to produce a 3-in.-diam hole. Samples of the core were collected during the process; however, the recirculating drilling fluids washed away most of the soft material from the upper zones. Because the drilling fluid was recirculated and came into contact with the core, grab samples of the drilling fluid were also collected to compare the ${ }^{3} \mathrm{H}$ activity in the fluid with the ${ }^{3} \mathrm{H}$ activities of the core samples.

Because the upper $5 \mathrm{ft}$ of the borehole is cased, it was necessary to put a separate well in the upper (soil and saprolite) zones for borehole flowmeter measurements. A second well was installed at Site 2 by coring and then pushing into place a slotted 2 -in.-ID PVC casing to a depth of approximately $7 \mathrm{ft}$.

\subsection{GROUNDWATER SAMPLE COLLECTION}

To determine seasonal variability in the transport of ${ }^{3} \mathrm{H}$ and ${ }^{90} \mathrm{Sr}$ from the study area, water samples were collected monthly from the seep and occasionally from a small drive-point well (Well 5-D) at Site 5 (Fig. 1) with a screened interval at about $9.5 \mathrm{ft}$ below the ground surface. Samples were collected at least two days after a rain (i.e., during nonstormflow conditions) with the exception of the sample collected in November soon after a rain of about 1 in. In 1989 a 1-in.-diam PVC pipe, slotted at the bottom, had been driven about 18 in. into the stream bank where the contaminated groundwater (seep) discharges. This small well was purged thoroughly each time before seep samples were collected from it. Well 5-D, installed in 1991, was pumped dry and allowed to recover partially prior to each sampling. Filtered samples were collected using a small peristaltic pump with silicon tubing and in-line filters $(0.45 \mu \mathrm{m})$. Samples for ${ }^{90} \mathrm{Sr}$ analysis were acidified $(\mathrm{pH}<2)$ with $\mathrm{HCl}$ after filtration. Occasionally not enough sample volume was collected from Well 5-D for ${ }^{90} \mathrm{Sr}$ analysis. 


\subsection{SAMPLE ANALYSIS}

\subsubsection{Tritium}

Because of the high ${ }^{3} \mathrm{H}$ activity, groundwater samples from Well 5-D and the seep were usually diluted by a factor of 10 prior to analysis. A procedure adapted from Environmental Protection Agency (EPA) Method 906.0 (EPA 1980) was used for the groundwater samples. A $100-\mathrm{mL}$ aliquot was distilled in an alkaline permanganate solution. Selected core samples (primarily shale) were heated and the evaporated water condensed. The distillates from the core samples were also often diluted because of the high ${ }^{3} \mathrm{H}$ activity.

Aliquots of $5 \mathrm{~mL}$ of the groundwater and core distiliates were mixed with $15 \mathrm{~mL}$ of liquid scintillation cocktail and counted for 100 min on a Packard 4640 liquid scintillation counter. A series of three EPA standards of known activity and a blank were distilled and counted using a quench-corrected efficiency curve. The ratio of the blank-corrected average of the known activities and the activities calculated from the efficiency curve served as a calibration factor for relating the instrument efficiency curve and the distillation procedure.

\subsubsection{Strontium-90}

Cerenkov radiation counting was us, to analyze the groundwater samples from Well 5-D and the seep for ${ }^{90} \mathrm{Sr}$ (Ross 1969). This technique utilizes the high energetic beta particle emitted during the decay of ${ }^{90} \mathrm{Y}$, which is the daughter of ${ }^{90} \mathrm{Sr}$. Aliquots of $20 \mathrm{~mL}$ of each sample were placed into plastic scintillation vials and analyzed in a liquid scintillation counter for $100 \mathrm{~min}$ (Larsen 1981). The ${ }^{90} \mathrm{Sr}$ activity in each sample was calculated by comparing the net count rate of the sample to that of a ${ }^{90} \mathrm{Sr}-{ }^{90} \mathrm{Y}$ standard after correcting for background blanks.

\subsection{ELECTROMAGNETIC BOREHOLE FLOWMETER}

The electromagnetic (EM) borehole flowmeter, an instrument developed by the Engineering Laboratory of Tennessee Valley Authority (TVA), has been used recently on the Oak Ridge Reservation (ORR) to determine the vertical extent and hydraulic properties of fractures in existing wells (Moore and Young 1992). The EM flowmeter technique has been shown to be cost-effective and a reliable method for identifying the zones of high and low permeability at ORNL in screened well intervals. The borehole flowmeter technique consists of measuring either natural or induced vertical flows at selected depths within a well. A change in flow between two depths indicates whether or not a permeable fracture occurs in the selected interval. The EM borehole flowmeter consists of a metal cylinder about 8 in. long and about 2 in. in diameter with a center hole for water flow. Two chloride electrodes contact the water in the center hole, and a magnetic coil is contained in the body of the cylinder. The groundwater acts as a conductor as it flows through the center hole, and the interaction of the conductor and the coil is measured as a voltage. A more complete description of the EM borehole flowmeter system can be found in a report by Young et al. (1991). Since the major focus of the investigation in SWSA 5 was to detect zones of high and low groundwater flows, a rigorous application of the EM flowmeter was not followed. 
Personnel from TVA provided and operated the EM flowmeter at the site in SWSA 5. Normally, an inflatable packer is used to fill the annulus between the 2-in.-diam flowmeter ancl the borehole wall. However, the packer was slightly too large for the 3-in.-diam borehole at the study site. Therefore, during the first survey which was run under ambient conditions in March, a portion of the vertical flow within the well passed around the flowmeter rather than through the center hole. A screened 2-in.-ID PVC casing was placed in the well as a guide. The flowmeter was placed just above the bottom of the borehole for the first measurement and then raised 1 to $2 \mathrm{ft}$ for subsequent measurements until the instrument was within the casing. After the instrument is moved to a new depth, it is necessary to wait a few minutes for the instrument readings to stabilize. The voltage signal is then averaged over a selected period of time, and the average reading is converted to flow in gallons per minute.

During the second survey in May, a Plexiglas collar was used around the instrument in an attempt to restrict flow around the flowmeter in the 3-in.-diam well. However, it cannot be determined how much of the vertical flow passed through the center hole. Also during the second survey, small peristaltic pumps were used to pump water into the well to induce vertical flow. A constant head of about $2 \mathrm{ft}$ above the static head was maintained by constantly pumping water (injection rate $\cong 0.1 \mathrm{gpm}$ ) into the well during the survey. Thus, flowmeter measurements beginning near the bottom of the well and taken at sequentially higher elevations produced a vertical profile of the discharge from the well.

A third flowmeter survey with induced flow of about $0.5 \mathrm{gpm}$ was conducted on the 2 -in.diam well in May. The instrument fit tightly in the casing of this small well. A constant head of about $2 \mathrm{ft}$ above the static head was maintained, and measurements were made at 0.5 - $\mathrm{ft}$ intervals.

\subsection{BOREHOLE DILUTION TEST}

The borehole dilution (also known as point-dilution) method can provide an estimate of the horizontal average specific discharge of the groundwater in the formation near the borehole and was utilized in this study as an addition to the EM flowmeter surveys to identify zones with the greatest groundwater flow. The test is performed by isolating a section of the borehole with packers and introducing a dye or other tracer to this interval. The interval is slowly mixed, and groundwater flow through the section gradually removes the tracer producing a dilution versus time relationship. The method is described in detail by Halevy et al. (1967) and Drost et al. (1968).

Instead of introducing a dye or tracer into the borehole at SWSA 5, distilled water was pumped into a test interval through the use of a small peristaltic pump. The test interval $(3.25 \mathrm{ft})$ was isolated by a dual packer system that was usually put into place a few days prior to the borehole dilution test so that the first water pumped from the intervai would be more representative of the water from the isolated groundwater zone. A closed system was used to maintain an equilibrium in the borehole interval (Fig. 5). As distilled water from a 25-L carboy was pumped in, water from the borehole interval was pumped out through a water quality meter manufactured by the Hydrolab Corporation, Austin, Texas. The meter has a flow-through cell and was used primarily to monitor specific conductance. Water exiting the meter then flowed back into the $25-\mathrm{L}$ carboy. After about $30 \mathrm{~min}$ the specific conductance 


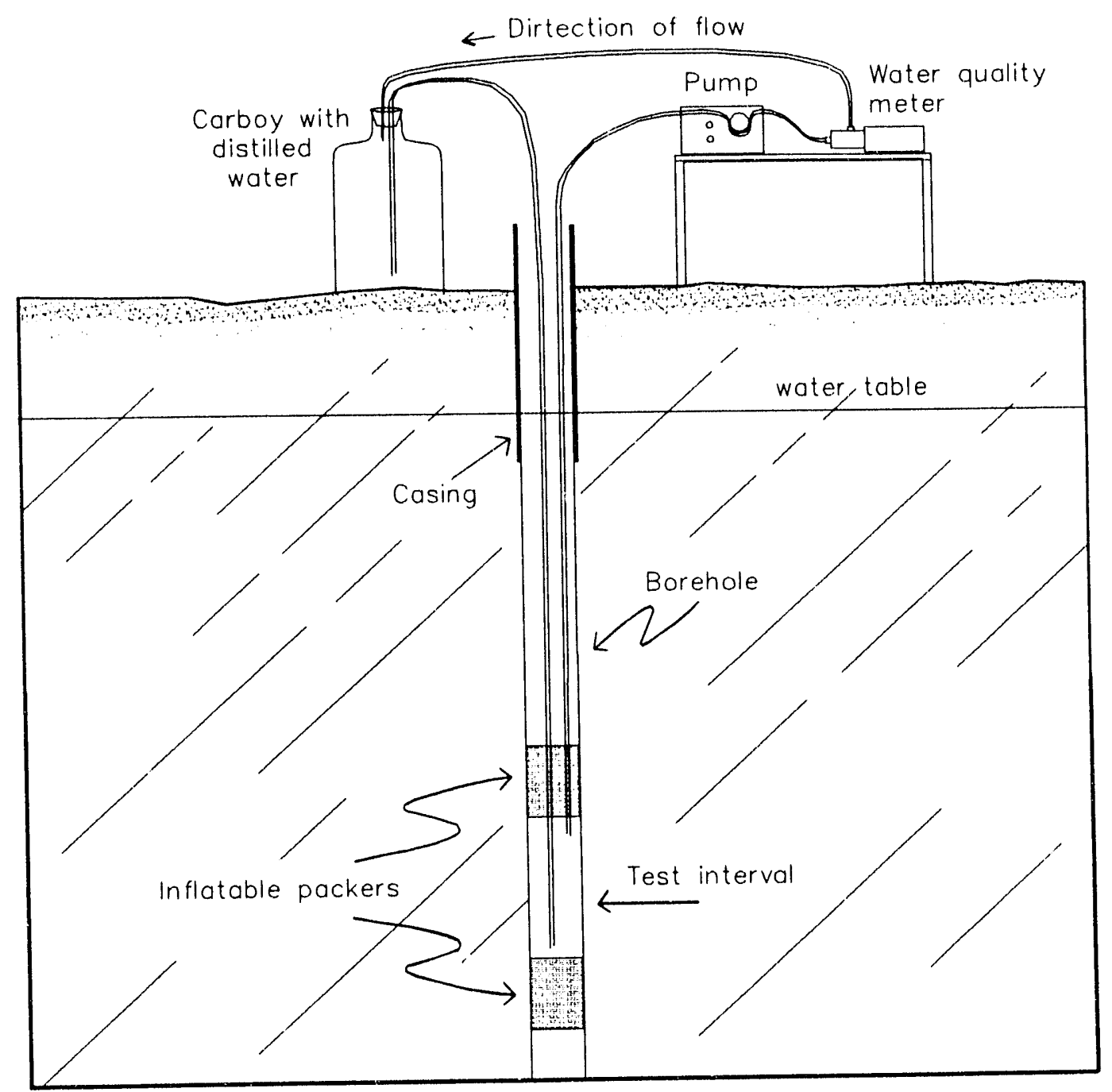

Fig. 5. Diagram of borehole dilution test setup.

in the interval was sufficiently low, and the 25 - $\mathrm{L}$ carboy was removed from the closed system. The pump rate was reduced just enough to slowly circulate the water in the interval and through the water quality meter for specific conductance measurements. The specific conductance of the interval was monitored over time (usually 5 to $6 \mathrm{~h}$ ) as the distilled water (low in dissolved ions) was slowly replaced with formation water (higher in dissolved ions). Borehole dilution tests were conducted on intervals at various depths within the borehole. 


\section{RESULTS}

\subsection{FIELD OBSERVATIONS}

The first $5 \mathrm{ft}$ of drilling below the casing (depth $=5.5$ to $10.5 \mathrm{ft}$ ) alternated between soft and hard zones. When the core barrel was retrieved, what remained of the core were brownish gray rock pieces (primarily shaley limestone) and one 8-in. coherent piece of gray limestone. Only a portion of the length that was drilled was recovered, indicating that most of the soft zones had been washed away by the drilling fluid. The limestone was highly fractured with secondary minerals (sometimes dolomite) filling the fractures. Many of the rock pieces were broken along dipping bedding planes, which had brownish surfaces. The drilling from $10.5 \mathrm{ft}$ to about $20 \mathrm{ft}$ continued to encounter intermittent soft and hard zones of grayish mud, thinly bedded shale, and limestone. Most of the soft zones were washed away by the drilling fluid. The extent of soft zones seemed to diminish in the remaining part of the hole (about 20 to $27 \mathrm{ft}$ depth), and more coherent cores of limestone and shale were obtained.

\subsection{TRITIUM DISTRIBUTION}

In 1991 the vertical extent of ${ }^{3} \mathrm{H}$ was determined only down to a depth of about $10 \mathrm{ft}$. To understand the subsurface transport and sources of ${ }^{3} \mathrm{H}$ in this area of SWSA 5, it is necessary to determine the ${ }^{3} \mathrm{H}$ activity at greater depths and relate them with the most hydrologically active zones. To gain knowledge of the ${ }^{3} \mathrm{H}$ activities in the formation at depths, core samples, primarily shale samples, from the borehole drilling were analyzed for ${ }^{3} \mathrm{H}$ (Table 1). Results suggest that the activity generally decreases with depth below $10 \mathrm{ft}$. However, because of the drilling method the results from the cores are tentative or should only be used as estimates of ${ }^{3} \mathrm{H}$ activities at depth. Cores were in contact with the drilling fluid, which began as tap water but during drilling mixed with groundwater as it was recirculated. The ${ }^{3} \mathrm{H}$ activity in the drilling fluid varied depending on the amount of tap water and groundwater but probably was always less than the activity in the cores (Table 1). Thus, ${ }^{3} \mathrm{H}$ activities of the core samples are likely less than the actual activity in the formation. This conclusion is supported by the groundwater sample that was collected during the initiation of a borehole dilution test in July from the interval 13 to $16.25 \mathrm{ft}$ deep which had $180 \mu \mathrm{Ci} / \mathrm{L}{ }^{3} \mathrm{H}$. Because the interval had been packed off (isolated) for 6 days, the activity may be fairly representative of the formation; however, it should still be noted that the entire borehole had been open for over 3 months. Plans have been made to install a multilevel sampling device from which it will be possible to obtain more reliable ${ }^{3} \mathrm{H}$ activities.

\subsection{ELECTROMAGNETIC BOREHOLE FLOWMETER}

Because it was not possible to pack off the annulus between the instrument and the borehole wall and some bypass of flow occurred, there are minor uncertainties in the EM borehole flowmeter results. However, some general delineations of flow zones can be interpreted from the data. The negative values from the first survey which was conducted under ambient conditions indicate that there are hydraulic head differences between permeable intervals within the borehole (Fig. 6). The head differences create upward flow 
from the lower zones (20 to $27 \mathrm{ft}$ ) which exits the hole between 15 to $20 \mathrm{ft}$. From the end of the casing to about $15 \mathrm{ft}$, essentially no flow was measured (i.e., there appears to be a zero offset of about $-0.02 \mathrm{gpm})$. An upward hydraulic gradient of 1.4 had been observed the previous year using drive-point wells at the lower site, Site 2 (Wickliff et al. 1991).

The discharge profile for the second survey in which water was injected into the borehole indicates that there is essentially no change (thus, no highly permeable interval) in the top $15 \mathrm{ft}$ (Fig. 7). The sharp change in flow from 15 to $18 \mathrm{ft}$ indicates that this zone is relatively the most permeable in the borehole.

The profile from the third EM borehole flowmeter survey (4 to $7 \mathrm{ft}$ depth) in the 2-in.diam well shows that the discharge from the well is fairly uniform with slightly gre iter discharge in the upper part of the screened interval (Fig. 8). The lack of any significant fracture zone in this region is consistent with the data from last year. Results in 1991 showed a close agreement between ${ }^{3} \mathrm{H}$ activities of samples from piezometers and ${ }^{3} \mathrm{H}$ activities of samples from cores, suggesting that advective transport (i.e., transport through fractures) is subordinate to diffusion over this same region (Wickliff et al. 1991).

Table 1. Tritium activities in extracted water from core samples

\begin{tabular}{lllcc}
\hline $\begin{array}{l}\text { Sample } \\
\text { ID }\end{array}$ & $\begin{array}{c}\text { Sample } \\
\text { date }\end{array}$ & $\begin{array}{c}\text { Sample } \\
\text { type }\end{array}$ & $\begin{array}{c}\text { Approximate } \\
\text { depth }(\mathrm{ft})\end{array}$ & $\begin{array}{c}{ }^{3} \mathrm{H} \\
(\mu \mathrm{Ci} / \mathrm{L})\end{array}$ \\
\hline & & & & \\
2A-D & $23 \mathrm{Mar} 92$ & Shale/mud & $9-10$ & 51 \\
2A-I & 24 Mar 92 & Shale & $13-15$ & 40 \\
2A-J & 24 Mar 92 & Shale/mud & $15-17$ & 37 \\
2A-M & 25 Mar 92 & Shale & $21-22$ & 9 \\
2A-O & 26 Mar 92 & Shale & $22-23$ & 20 \\
2A-P & 26 Mar 92 & Shale & $23-23.5$ & 10 \\
2A-R & 26 Mar 92 & Shale & $24-24.5$ & 6 \\
2A-V & 27 Mar 92 & Shale & $26-27$ & 12 \\
Slush 1 & 24 Mar 92 & Drilling fluid & & 4 \\
Slush 2 & 24 Mar 92 & Drilling fluid & & 1.3 \\
\hline
\end{tabular}




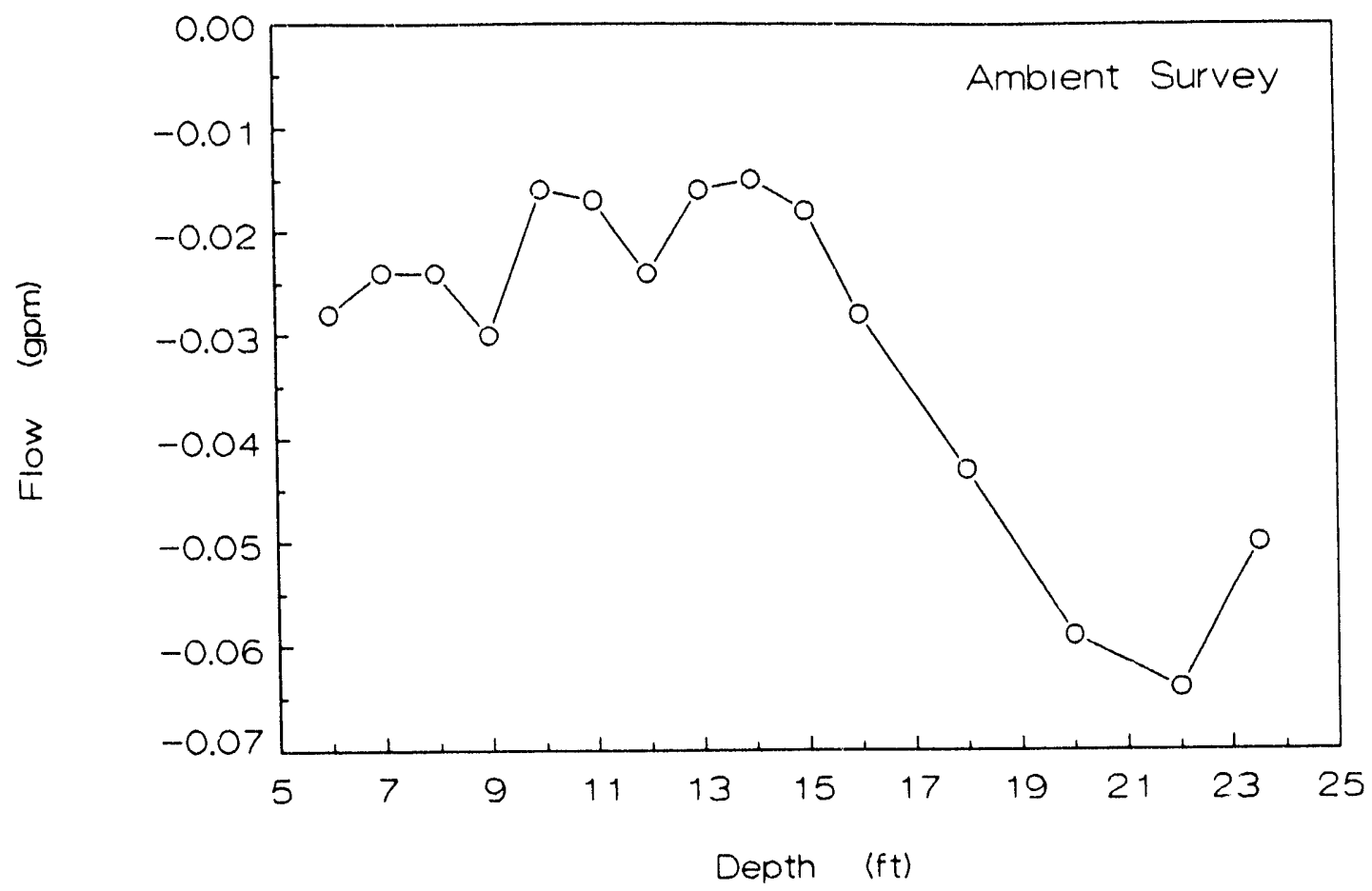

Fig. 6. Results from borehole flowmeter survey conducted during ambient conditions.

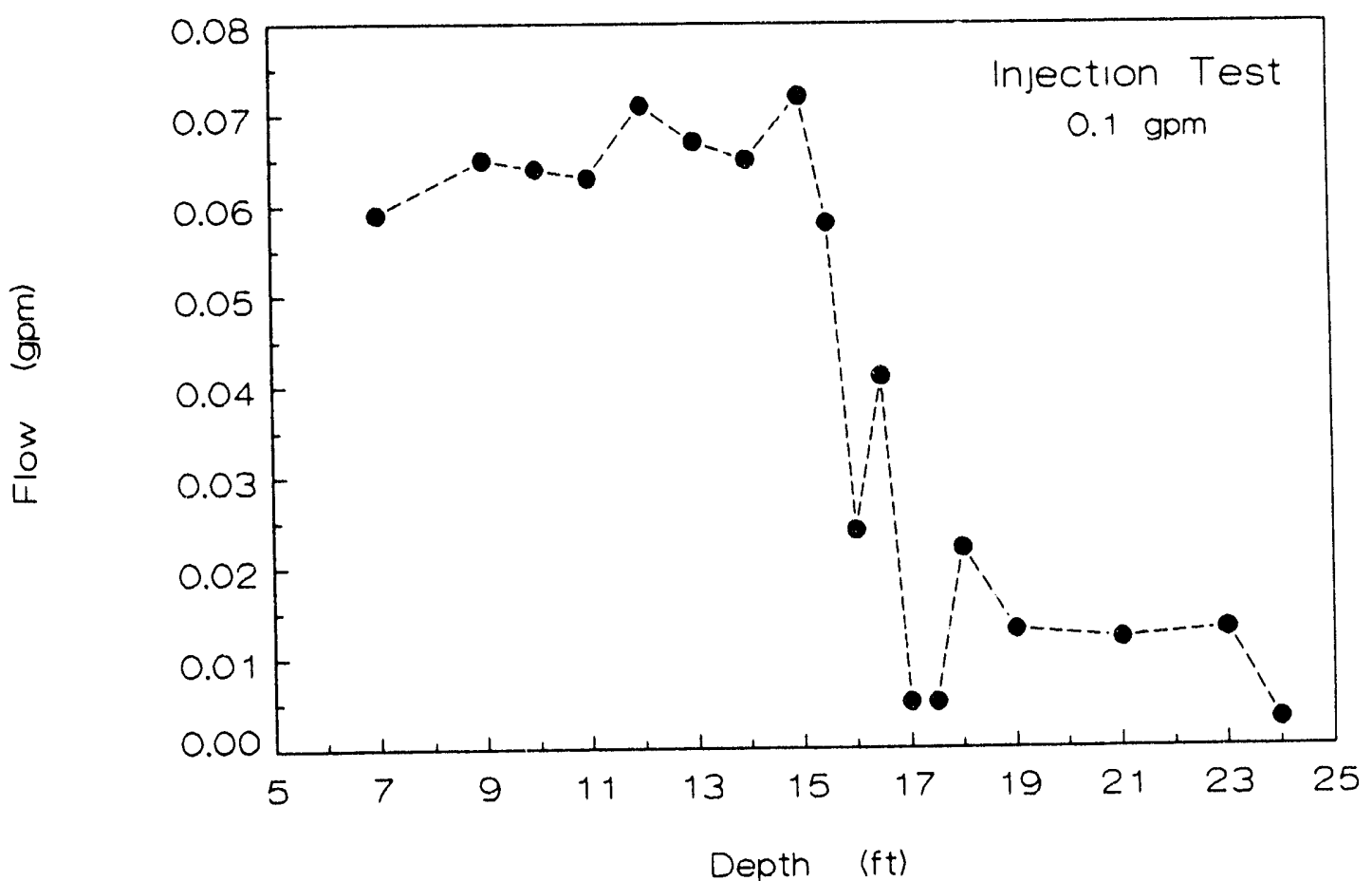

Fig. 7. Results from borehole flowmeter survey conducted while maintaining a constant head by injection. 


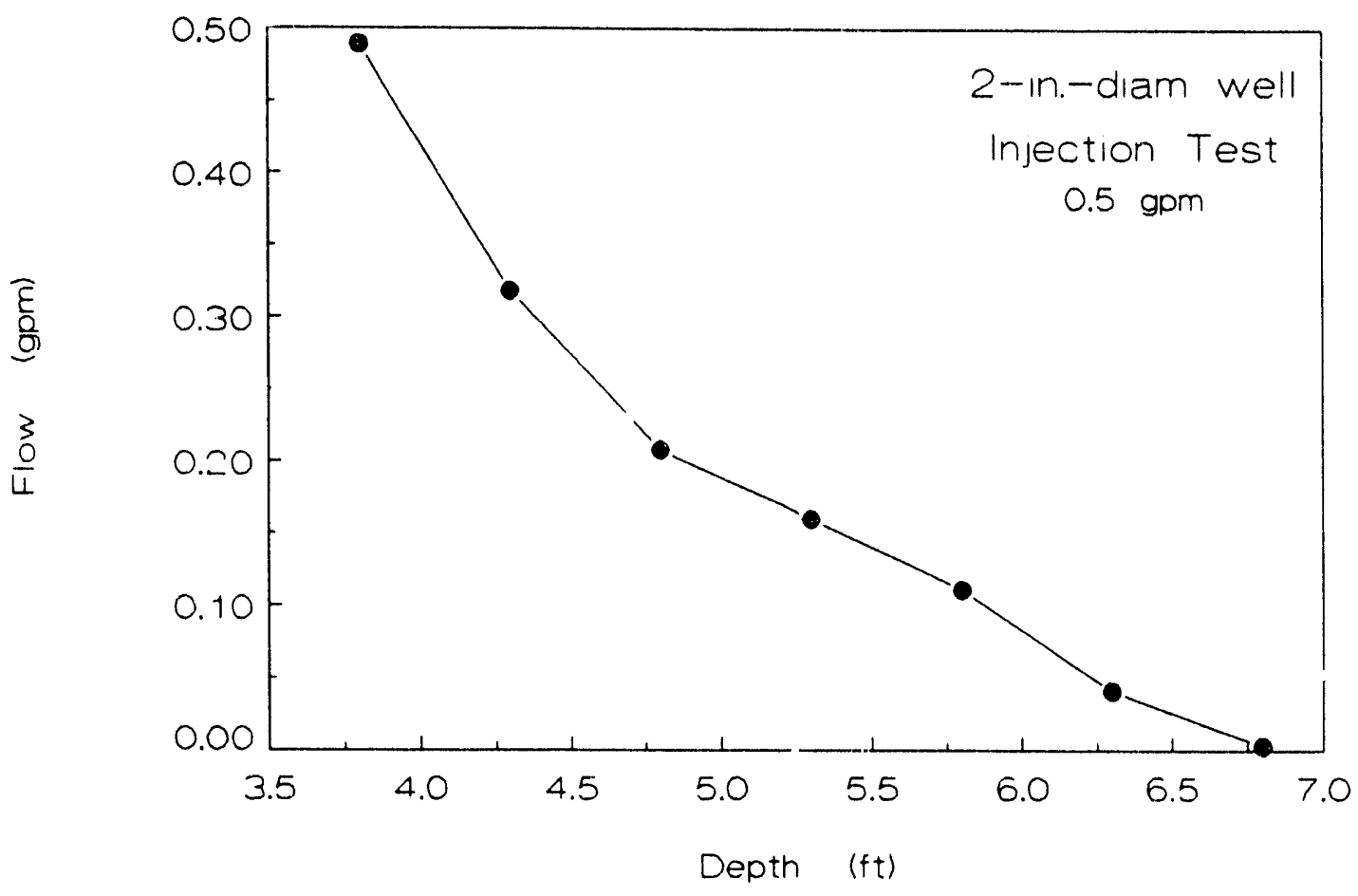

Fig. 8. Results from borchole flowmeter survey conducted on 2-in.-diam well while maintaining a constant head by injection.

\subsection{BOREHOLE DILITION TESTS}

Initially three borehole dilution tests were conducted before the seven listed in Table 2. During the initial tests it was evident that there was a problem with gravity causing the distilled water to $t$ e fed from the carboy down into the packed-off interval faster than water was being pumped out of the interval. Thus, the groundwater system was stressed as distilled water was pushed into the surrounding formation. During the following dilution tests the tubing from the carboy to the well interval was restricted in an attempt to equilibrate the flow going in with the flow being pumped out. At the beginning of pumping the specific conductance of the first water from the well was considered to be representative of the specific conductance of the formation within the interval packed off. The specific conductance values were generally greater at depth and ranged from 705 to $917 \mu \mathrm{S} / \mathrm{cm}$ (Table 2). As pumping continued the distilled water from the carboy entered the interval, lowering the conductance. An example of the response of specific conductance within a packed off interval is shown in Fig. $\%$. 
Table 2. Specific discharge in each interval computed from borchole dilution tests

\begin{tabular}{cccccl}
\hline $\begin{array}{c}\text { Borehole } \\
\text { interval } \\
(\mathrm{ft})\end{array}$ & $\begin{array}{c}\text { Test } \\
\text { date }\end{array}$ & $\begin{array}{c}\text { Specific } \\
\text { conductance } \\
\text { before test }\end{array}$ & $\begin{array}{c}\text { Specific discharge } \\
\text { (ft/day) }\end{array}$ & (m/year) & Comments \\
\hline & & & & & \\
$7-10.25$ & 8 Jul 92 & 705 & 0.29 & 32 & Upgradient drilling during test \\
$10-13.25$ & 15 Jul 92 & 770 & 0.42 & 47 & Packers not in place long \\
$12-15.25$ & 27 Apr 92 & 883 & 1.15 & 128 & Based on limited data \\
$13-16.25$ & 7 Jul 92 & 893 & 1.46 & 162 & Upgradient drilling during test \\
$15-18.25$ & 23 Apr 92 & 860 & 0.71 & 79 & Packer not in place long \\
$18-21.25$ & 22 Apr 92 & 917 & 0.38 & 42 & \\
$20-23.25$ & 15 Apr 92 & 890 & 0.29 & 32 & Packer not in place long \\
\hline
\end{tabular}

Estimates of groundwater flux for the different intervals or zones were calculated from the borehole dilution tests by solving the following mass balance equation.

$$
C_{f} q A-C_{b} q A=\frac{d C_{b}}{d t} V
$$

where

$\boldsymbol{A}=$ cross-sectional area of borehole interval,

$V=$ volume of borehole interval,

$C_{f}=$ specific conductance in the formation before any disturbance,

$C_{b}=$ specific conductance in the borehole interval at any time $t$,

$\boldsymbol{q}=$ specific discharge in the borehole interval,

$t=$ time.

Rearrangement of Eq. (1) gives

$$
\frac{d C_{b}}{C_{f}-C_{b}}=\frac{q A}{V} d t
$$

and integration of Eq. (2) with the initial conditions of $C_{b}=C_{0}$ at $t=0$ yields

$$
-\ln \left[\frac{C_{f}-C_{b}}{C_{f}-C_{o}}\right]=\frac{q A}{V} t
$$

where $C_{0}$ is the initial specific conductance after injection of distilled water.

Figures 10 through 16 present the dilution test results graphed as $-\ln \left[\left(C_{f} C_{b}\right) /\left(C_{f} C_{o}\right)\right]$ versus time. 


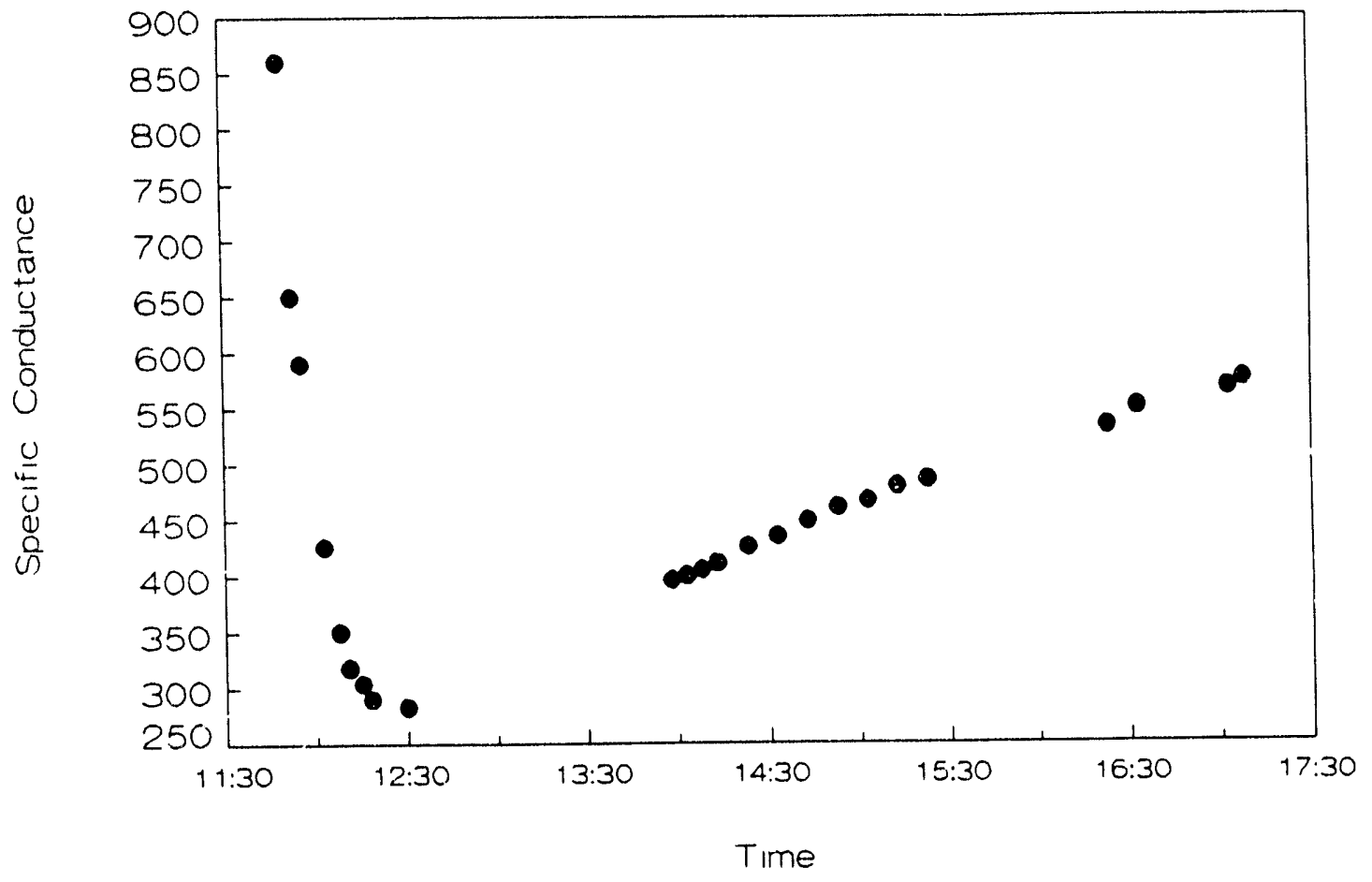

Fig. 9. Typical response of specific conductance within an interval during a borehole dilution test.

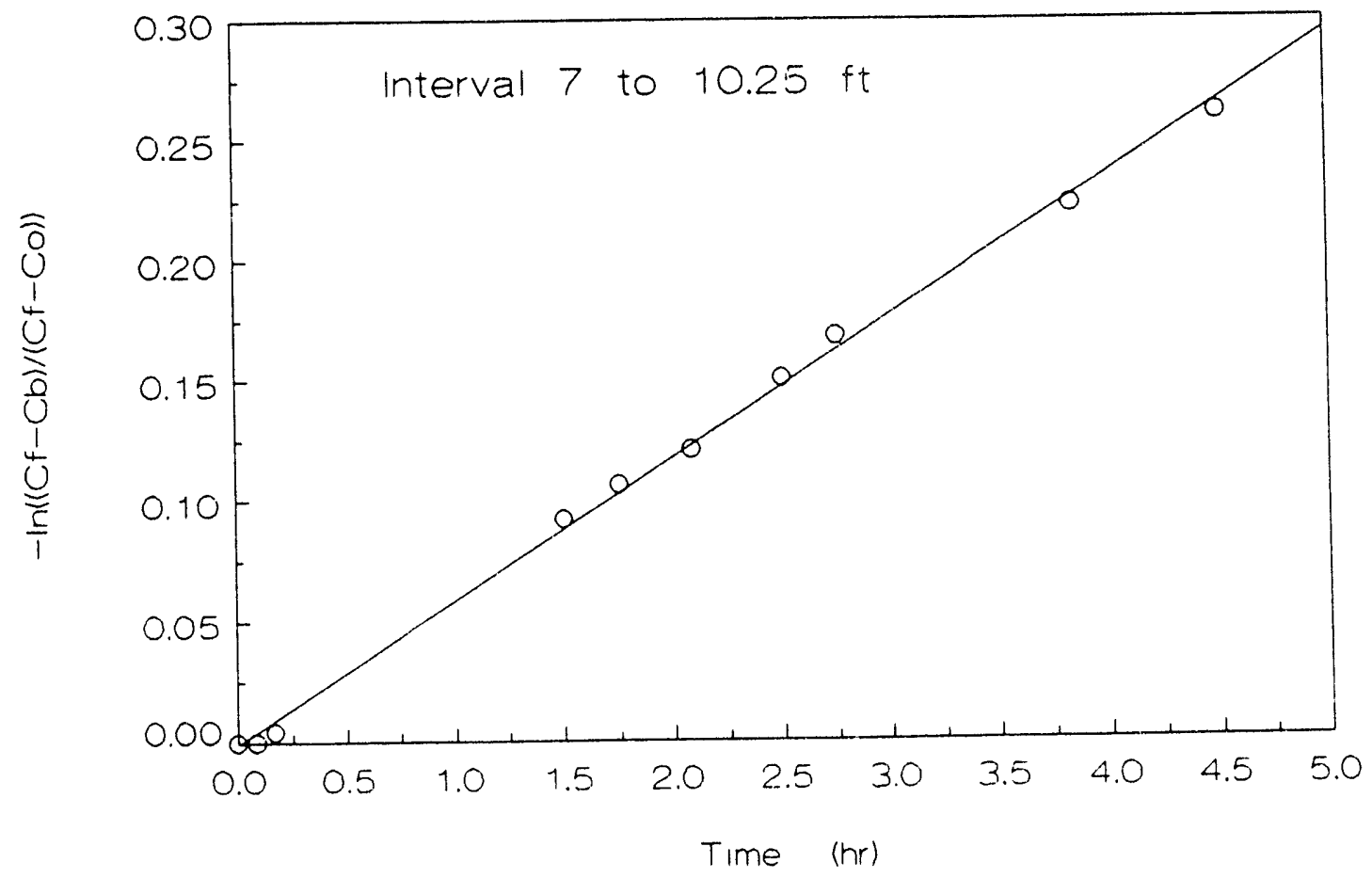

Fig. 10. Borehole dilution test results from the 7- to 10.25 -ft interval. 


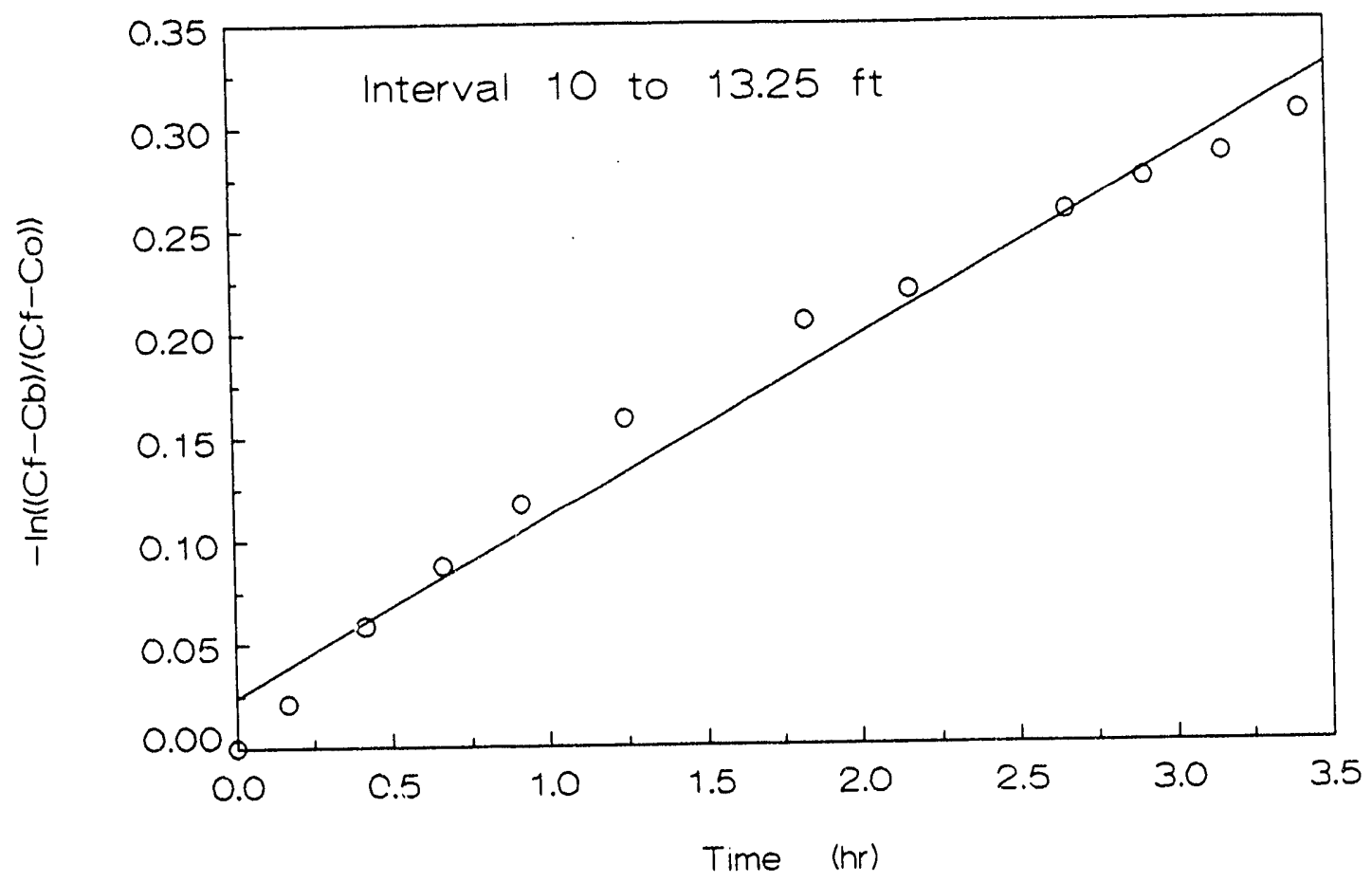

Fig. 11. Borehole dilution test results from the 10 - to 13.25 -ft interval.

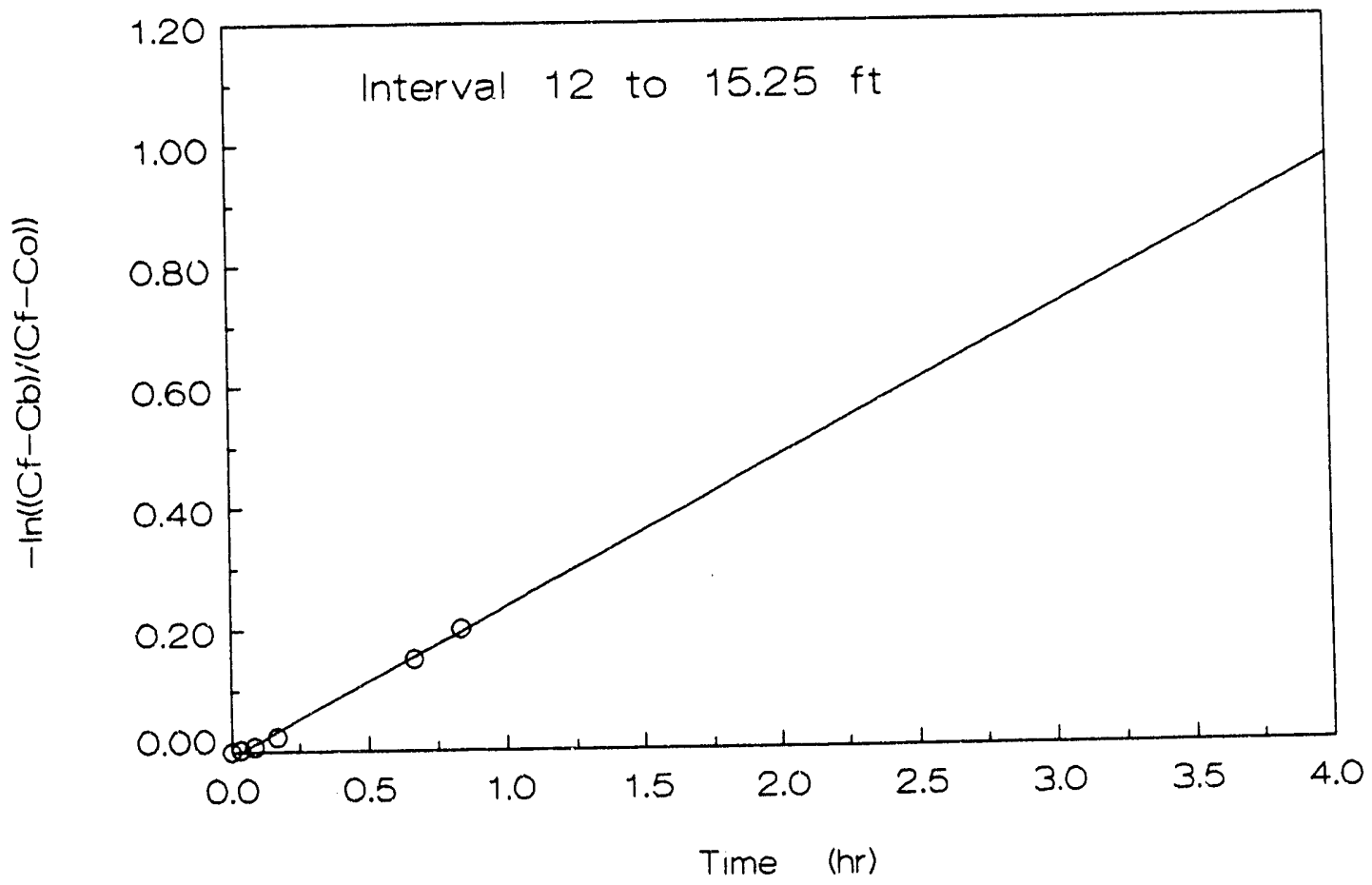

Fig. 12. Borehole dilution test results from the 12 - to 15.25 -ft interval. 


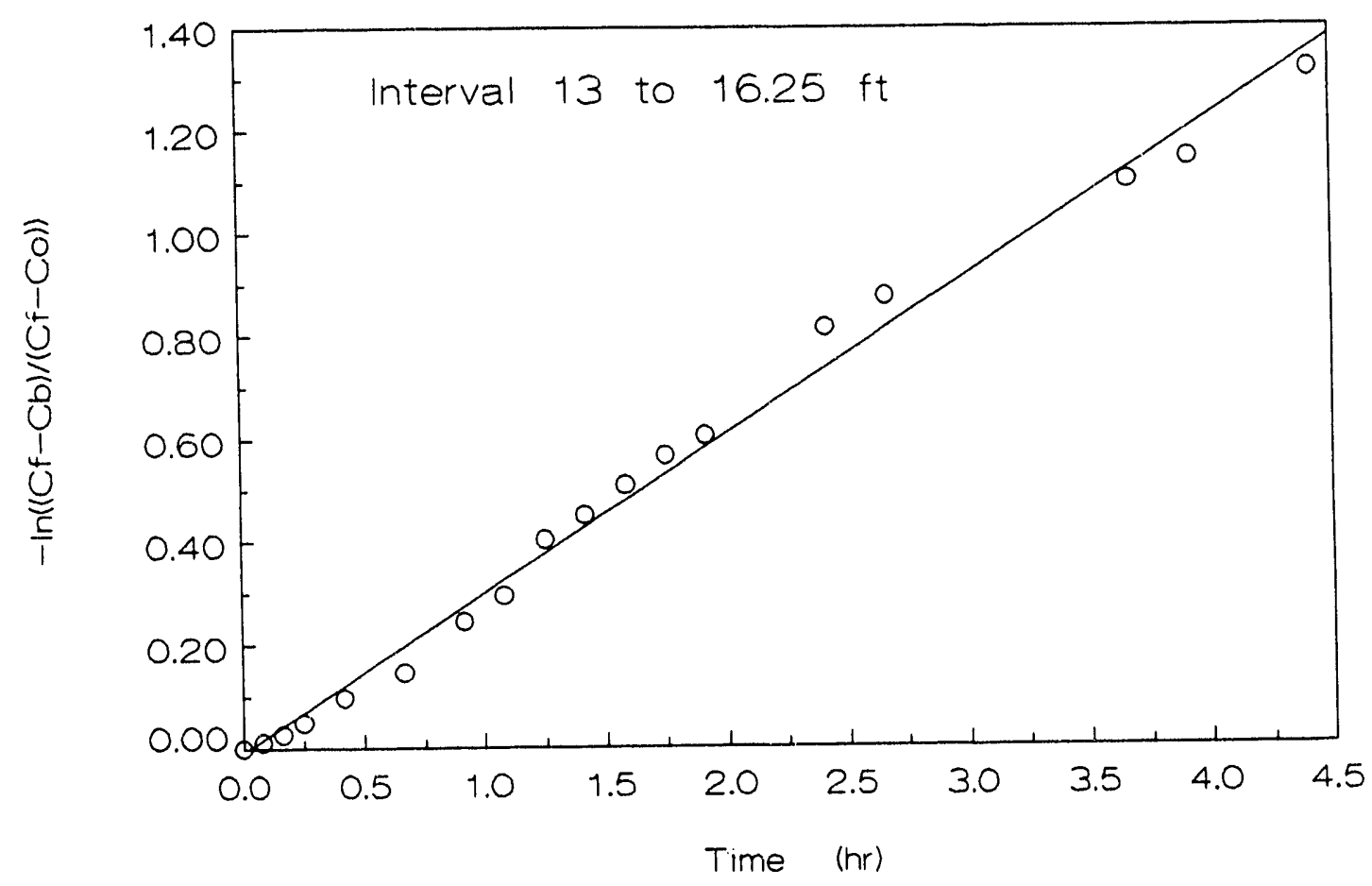

Fig. 13. Borehole dilution test results from the 13- to 16.25 -ft interval.

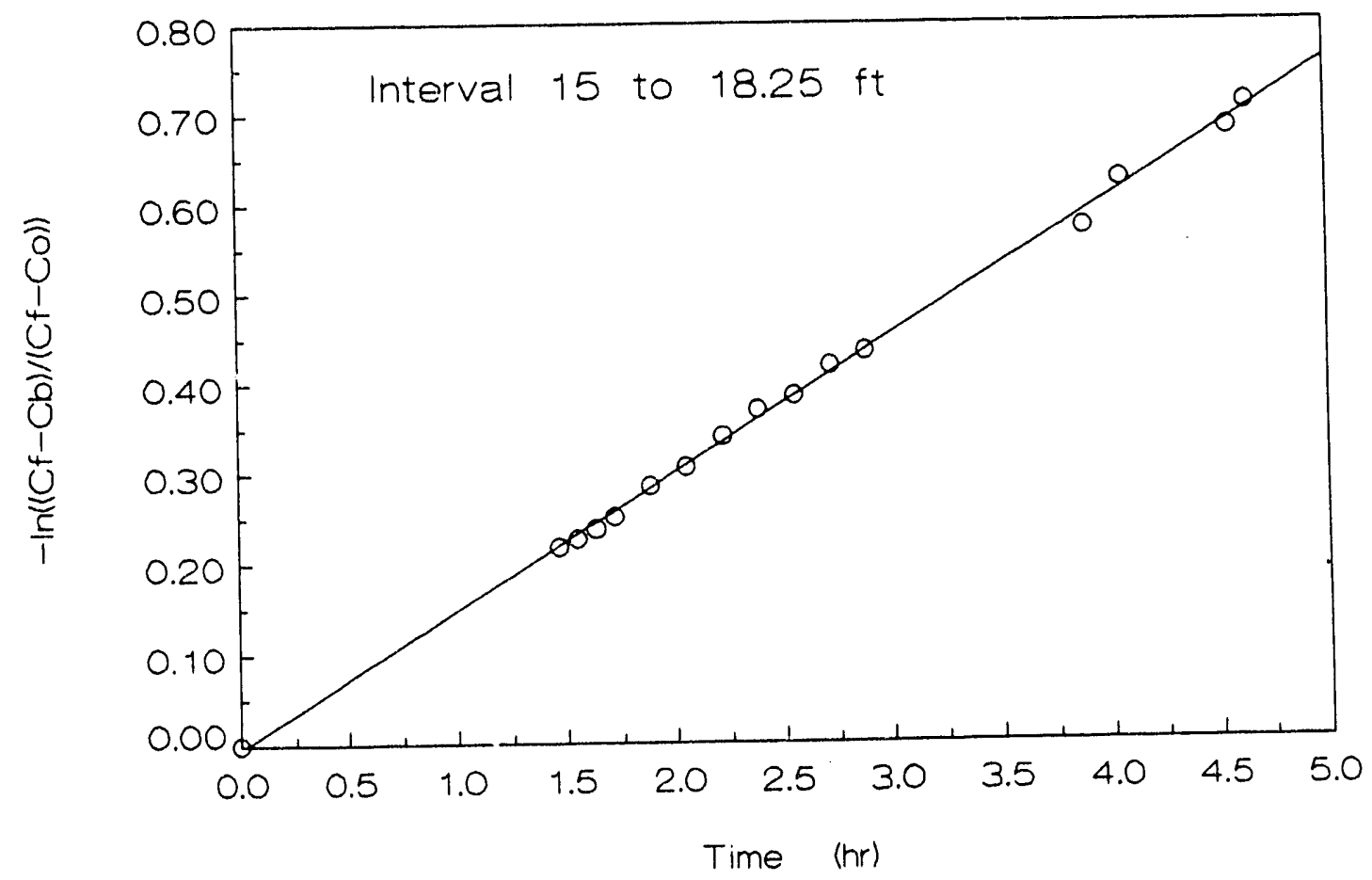

Fig. 14. Borehole dilution test results from the 15- to 18.25-ft interval. 


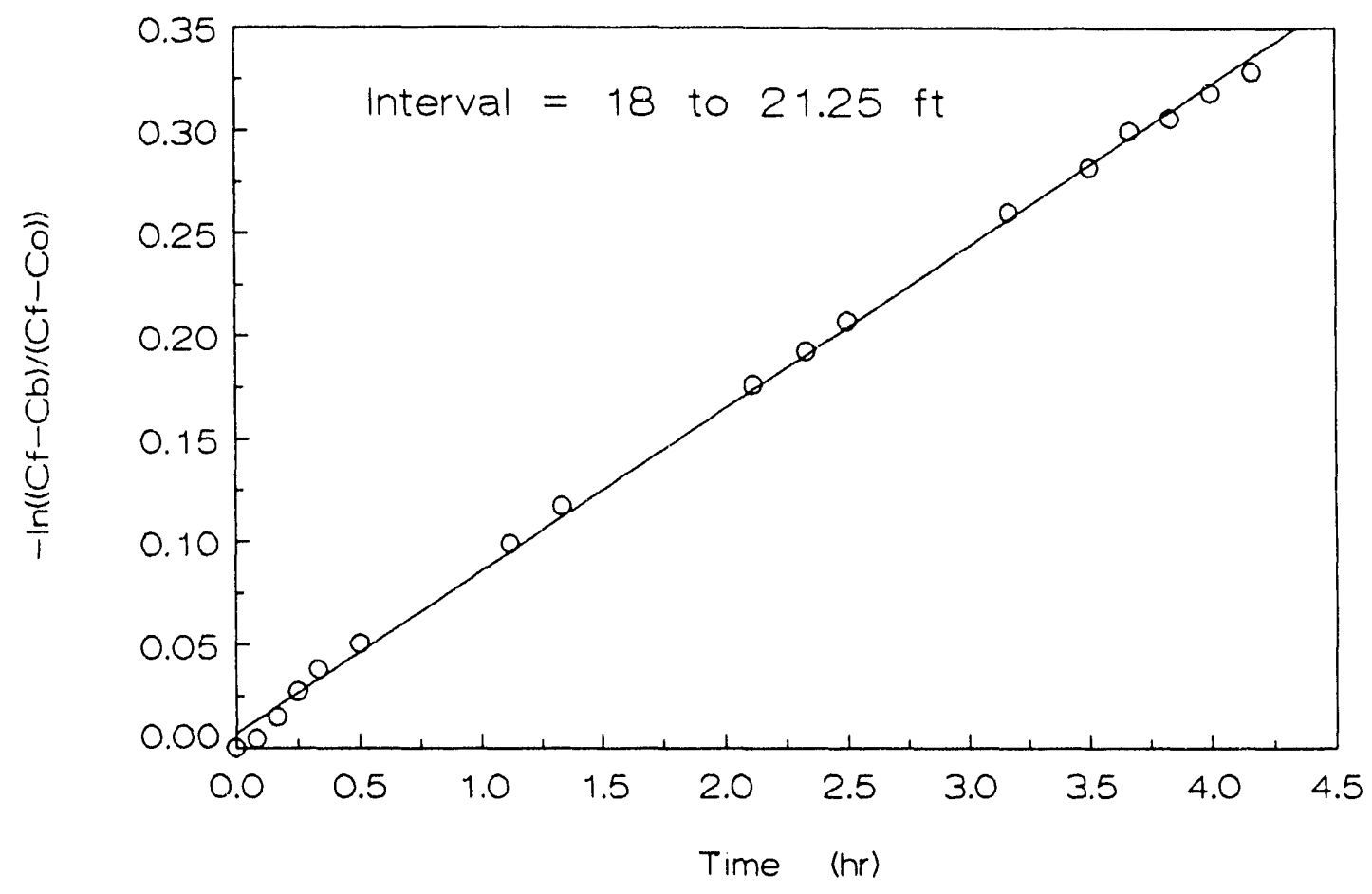

Fig. 15. Borehole dilution test results from the 18- to 21.25-ft interval.

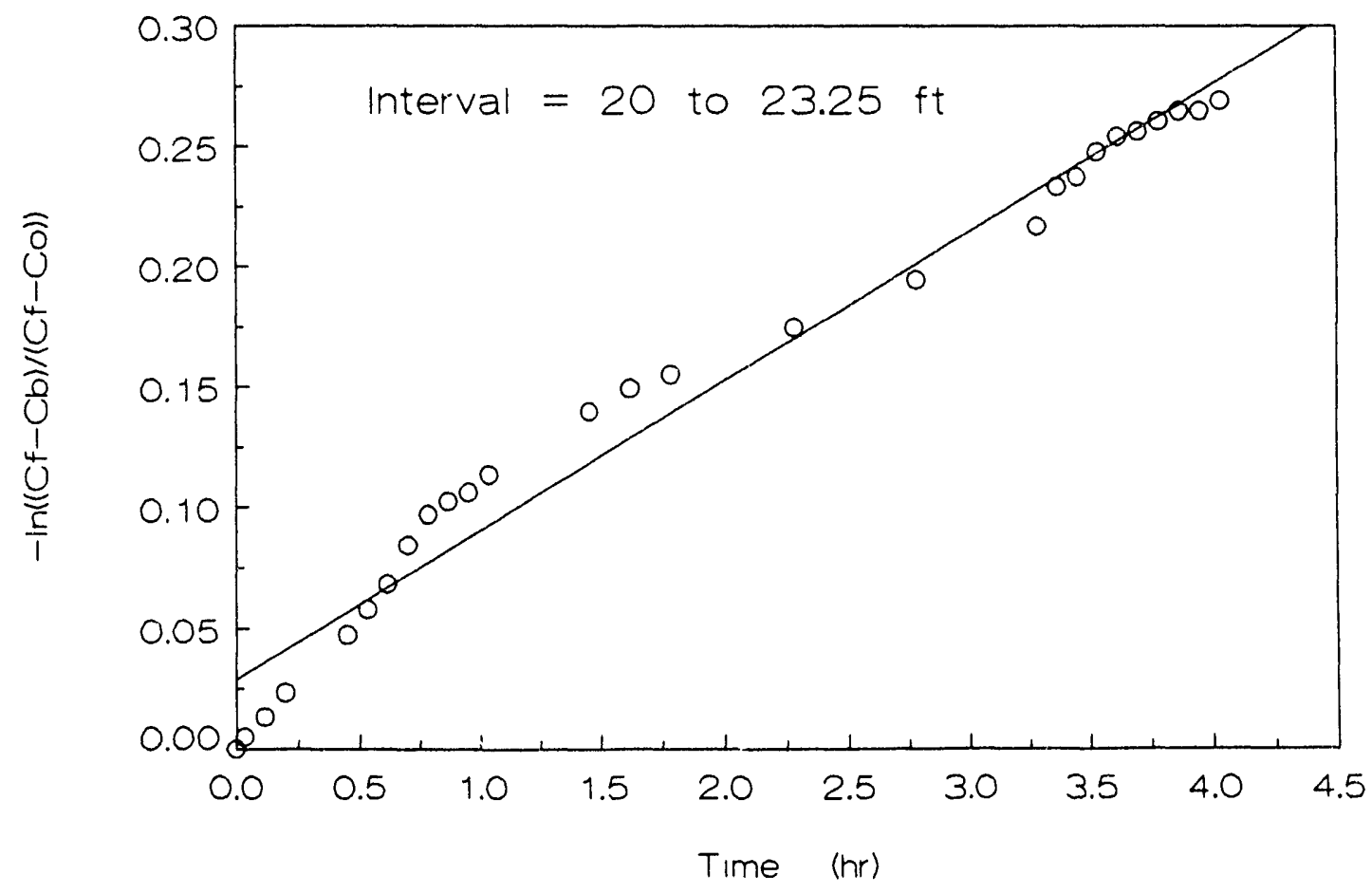

Fig. 16. Borehole dilution test results from the 20- to 23.25 -ft interval. 
Because Eq. (3) is linear, a line through the data using the least square regression method yields an optimized fit of the data where

$$
\text { slope }=\frac{q A}{V}
$$

Thus, the specific discharge in each borehole interval can be computed as

$$
q=\operatorname{slope} \frac{V}{A}
$$

Table 2 gives the specific discharge in each of the borehole intervals calculated from the slope of the best fit line. Data for the interval from 12 to $15.25 \mathrm{ft}$ were limited (Fig. 12) because of packer problems in April but suggested a permeable zone in this interval. The presence of a permeable fracture or fractures in this area was supported by the borehole dilution test conducted in July for the interval from 13 to $16.25 \mathrm{ft}$. This interval had the greatest specific discharge of $1.46 \mathrm{ft} /$ day $(162 \mathrm{~m} / \mathrm{year})$, which was 3.5 to 5 times greater than all of the other intervals with the exception of the interval 15 to $18.25 \mathrm{ft}$, which had a specific discharge of $0.71 \mathrm{ft} /$ day ( $79 \mathrm{~m} /$ year) (Table 2). It should be noted that these values represent the specific discharge, $q$, in the borehole which is related to the specific discharge in the formation, $\boldsymbol{q}^{*}$, by a borehole factor, $\boldsymbol{a}$.

$$
q *=\frac{q}{a}
$$

Because groundwater streamlines will converge towards an open borehole, the specific discharge in the formation will generally be less than in the borehole. Studies at other sites indicate that the borhole factor, $a$, ranges between 1 and 3 , although precise values for the ORR have not been determined.

The following possible sources for error in the borehole dilution tests should be noted: (1) borehole dilution tests are best suited for determining lateral velocity in systems where there is little vertical flow; (2) if walls of the borehole are rough, there could have been some leakage around the packers which would produce a greater than actual value for specific discharge; (3) because of the difficulty in regulating the rate that distilled water was fed down into the interval (i.e., keeping an equilibrium between water removed and water replaced), the groundwater system may have been slightly stressed; (4) the tests took place during different times (April and July), and temporal variations in the natural hydraulic heads may have affected the results (i.e., it may not be valid to relate the specific discharge in one interval with that in another if the measurements were made during different seasons); (5) the later tests were conducted at the same time another borehole was being drilled only about $50 \mathrm{ft}$ upgradient; thus, drilling fluid and different stresses on the system may have affected the results. However, even with these potential errors the results from the dilution tests, which suggest that the highest water-bearing zone is within the interval 13 to $16.25 \mathrm{ft}$, correspond quite well with the results from the borehole flowmeter tests, which indicate that the zone from 15 to $18 \mathrm{ft}$ is relatively the most permeable in the borehole (Fig. 17). 


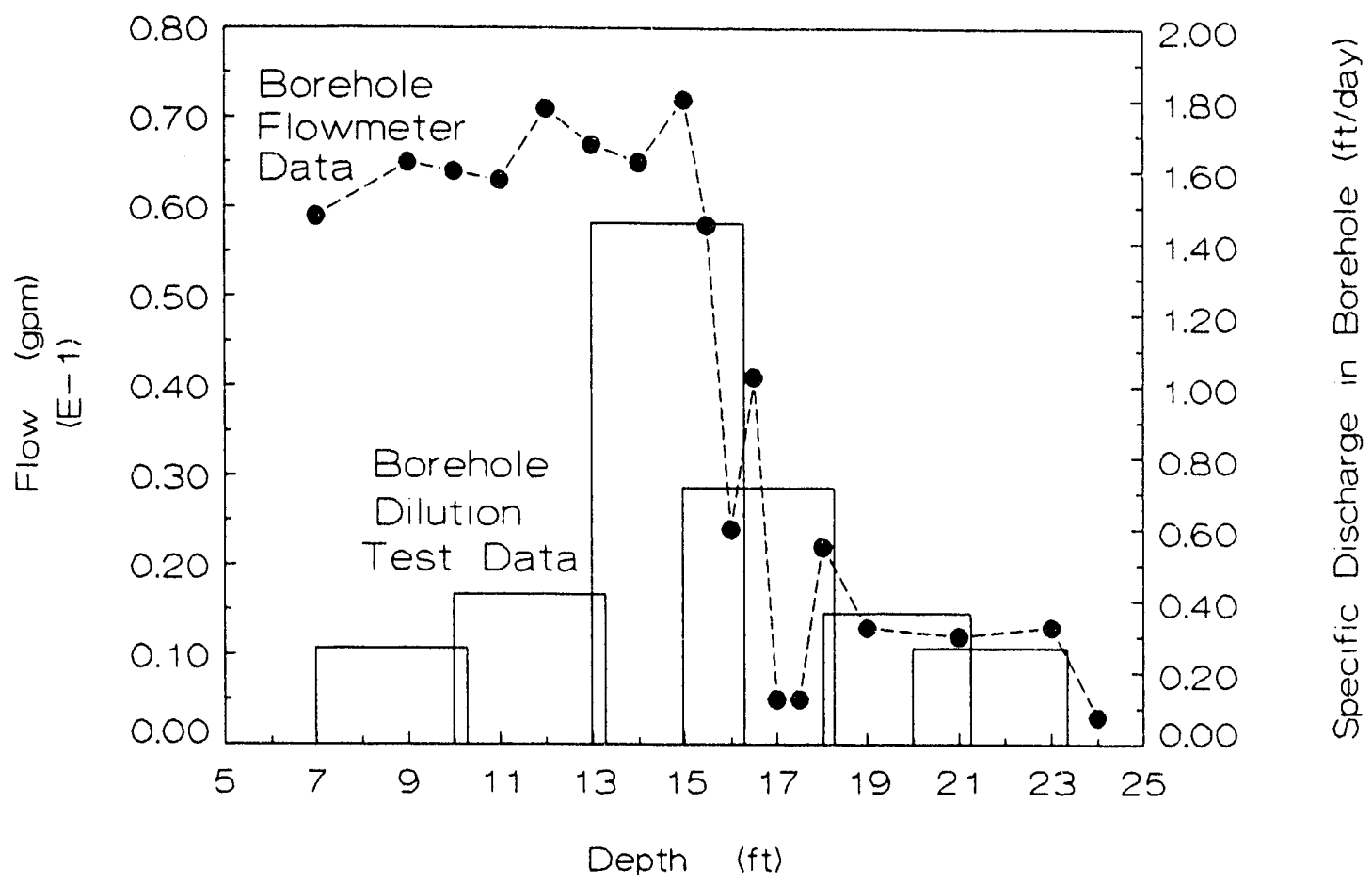

Fig. 17. Borehole flowmeter and borehole dilution results.

\subsection{COMPARISON OF BOREHOLE DILUTION RESULTS WITH OTHER DATA}

Because the calculation of specific discharge from the borehole dilution results requires an empirical borehole factor, $a$, it is important to compare the dilution values with independent data. Groundwater discharge can be estimated from the borehole dilution results and compared with groundwater discharge estimates using strearn flow data. Stream flow in Melton Branch (MB) in 1988 was $9.8 \times 10^{5} \mathrm{~m}^{3} / y e a r$ of which $56 \%$ was estimated to be baseflow (i.e., groundwater discharge without stormflow) (Solomon et al. 1991). The area in SWSA 5 which contributes to the reach of MB and Melton Branch Tributary (MBT) is approximately $12 \%$ of the total drainage area of MB. Thus, the amount of groundwater discharge from this reach using stream discharge data for 1988 was about $0.66 \times 10^{5} \mathrm{~m}^{3} / \mathrm{year}$. Groundwater discharge along this reach can be estimated by using specific discharge values determined via the borehole dilution technique by assuming that most of the groundwater discharge occurs over the depth from 7 to $23.25 \mathrm{ft}$. Using an integrated specific discharge value $(65.7 \mathrm{~m} / \mathrm{year})$ from the specific discharge values in Table 2 , we estimate that the groundwater discharge from SWSA 5 would be about $2.6 \times 10^{5} \mathrm{~m}^{3} /$ year for the MB and MBT reach of $800 \mathrm{~m}$. The two estimates of groundwater discharge from this reach, $0.66 \times 10^{5}$ $\mathrm{m}^{3} /$ year and $2.6 \times 10^{5} \mathrm{~m}^{3} / \mathrm{year}$, differ by only a factor of 4 , which suggests that the specific discharge values are reasonable.

It is also possible to evaluate the specific discharge values determined via the borehole dilution technique by mass balancing the ${ }^{3} \mathrm{H}$ mass flow in MBT. Figure 18 shows the ${ }^{3} \mathrm{H}$ mass flow in MB and MBT during base flow conditions in 1988. The change in mass flow from 0 to $4 \mu \mathrm{Ci} / \mathrm{s}$ between Stations 2825 and 2400 represents a ${ }^{3} \mathrm{H}$ input from the seep (Fig. 1) with 


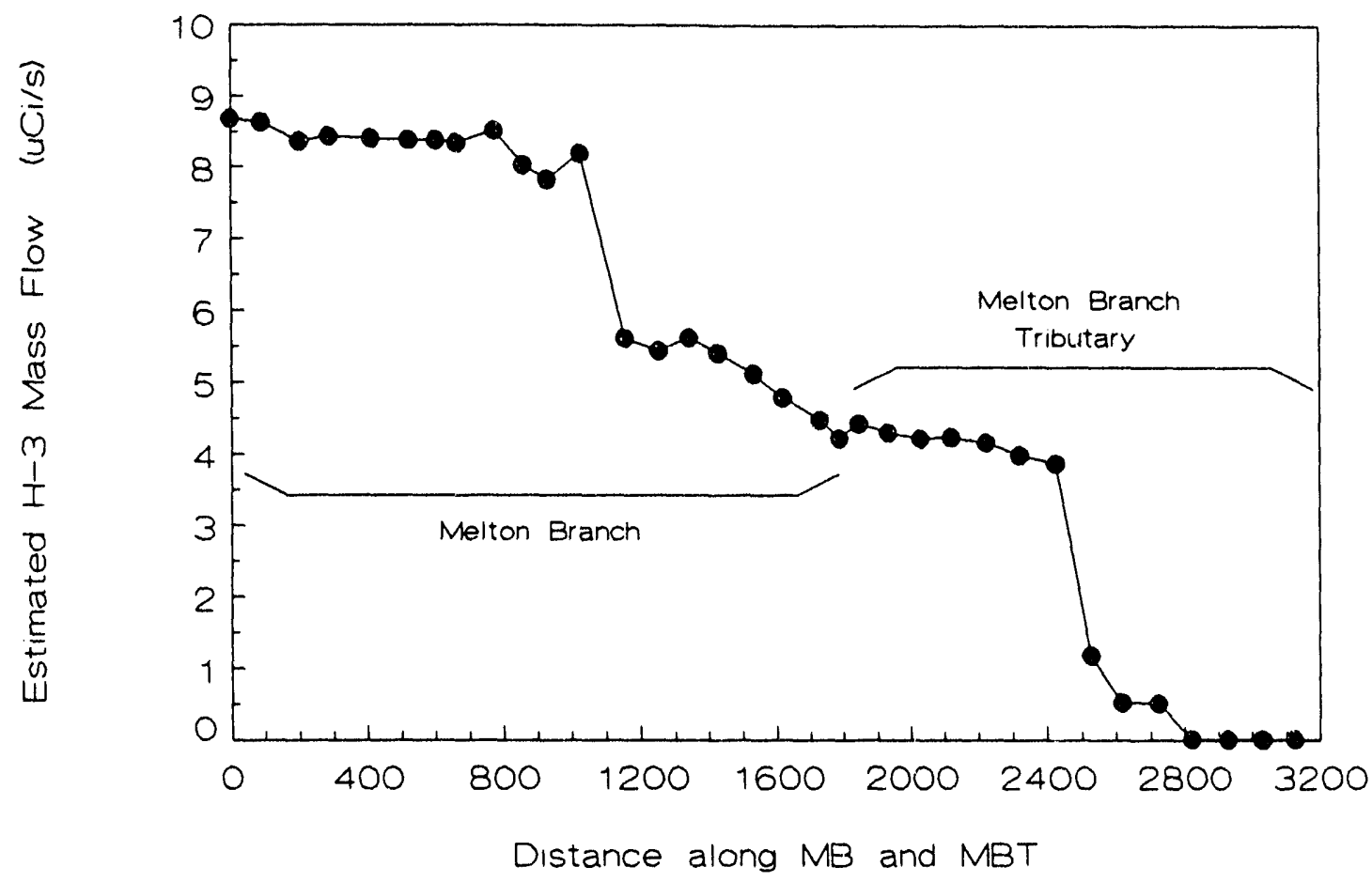

Fig. 18. Tritium mass flow in Melton Branch and Melton Branch Tributary.

the majority of the input occurring between Stations 2400 and 2475 . Thus, in $1988{ }^{3} \mathrm{H}$ discharge ranged from 3 to $4 \mu \mathrm{Ci} / \mathrm{s}$ into $\mathrm{MBT}$ during baseflow conditions over a distance between 75 and $425 \mathrm{ft}$.

An independent estimate of the ${ }^{3} \mathrm{H}$ mass flow in the seep can be made by combining estimates of the vertical distribution of ${ }^{3} \mathrm{H}$ activities with the vertical distribution of specific discharge values from the borehole dilution tests (Fig. 19). Most of the estimates of ${ }^{3} \mathrm{H}$ activities from 9 to $27 \mathrm{ft}$ below land surface are from pore water extracted from cores; however, these values are thought to be low because of the dilution by drilling fluids. One undiluted ${ }^{3} \mathrm{H}$ value $(180 \mu \mathrm{Ci} / \mathrm{L})$ is available from the interval 13 to $16.25 \mathrm{ft}$ below land surface. This value has been used to correct for dilution in the core samples. Combining the dilutioncorrected ${ }^{3} \mathrm{H}$ values with the specific discharge estimates and integrating over the depth from 7 to $23.25 \mathrm{ft}$ below land surface, we estimate the ${ }^{3} \mathrm{H}$ mass flow to be $0.38 \mu \mathrm{Cis}^{-1} \mathrm{~m}^{-1}$. This value is the mass flow per unit width of the seep and compares well with the ${ }^{3} \mathrm{H}$ mass flow in MBT if the mean width of the ${ }^{3} \mathrm{H}$ plume is about $30 \mathrm{ft}$.

While there are many assumptions in the previous comparisons (i.e., the stream discharge and mass flow in MB and MBT in 1988 are the same as in 1992; the groundwater discharge and ${ }^{3} \mathrm{H}$ mass flow above $7 \mathrm{ft}$ and below $23 \mathrm{ft}$ are insignificant; and pore fluid dilution corrections are valid), these comparisons do suggest that the specific discharge values are reasonable and are likely to be within a factor of 4 of the true values (which is close to the range of the borehole correction factors observed in other studies). 


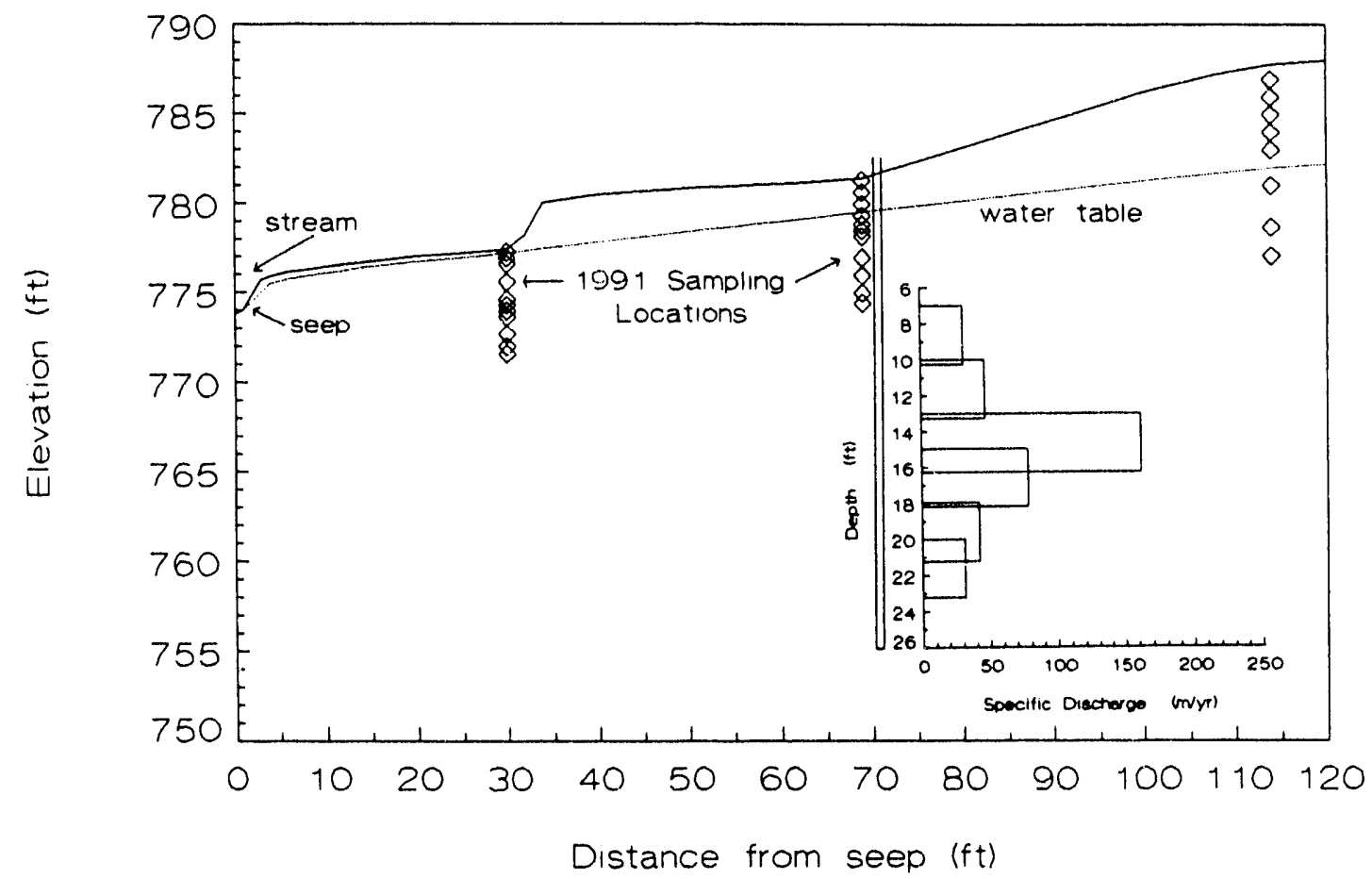

Fig. 19. Cross section of study area relating specific discharge values with subsurface zones.

\subsection{SEASONAL VARIABILITY OF CONTAMINANT DISCHARGE}

Tritium and ${ }^{90} \mathrm{Sr}$ activities in the seep and well samples varied over the sampling period from April 1991 to June 1992 (Figs. 20 and 21). Tritium activities were the greatest in the seep and ranged from 78 to $128 \mu \mathrm{Ci} / \mathrm{L}$, whereas ${ }^{3} \mathrm{H}$ activities in Well $5 \mathrm{D}$ (9.5 ft deep) ranged from 25 to $69 \mu \mathrm{Ci} / \mathrm{L}$ (Fig. 18). Strontium-90 activities were greatest in Well 5D near the trenches and ranged from 13 to $23 \mathrm{nCi} / \mathrm{L}$, whereas the activities in the seep ranged from 3.1 to $3.9 \mathrm{nCi} / \mathrm{L}$ (Fig. 20). A primary flowpath for the tritiated groundwater that discharges at the seep must be below the zone that is intercepted by the ivell at site 5. However, a small amount of shallow subsurface lateral flow may be transporting the ${ }^{90} \mathrm{Sr}$ from the nearby trenches and discharging at the seep. Variations in hydrologic conditions (seasons) appear to govern both ${ }^{3} \mathrm{H}$ and ${ }^{90} \mathrm{Sr}$ activities in the seep, with activities being lowest during the wetter (winter) season and higher in the late spring and summer when conditions are drier. Although the activities are lower during the wetter season, groundwater discharge from the seep is likely greater. Thus, to determine the variability in the actual release (activity $\times$ discharge) of ${ }^{3} \mathrm{H}$ and ${ }^{90} \mathrm{Sr}$ from the seep, it will be necessary to determine the variability of groundwater discharge from this area. Monitoring ${ }^{3} \mathrm{H}$ and ${ }^{90} \mathrm{Sr}$ activities in the seep and stream (MBT) in conjunction with stream discharge would provide a way for determining changes in release of these contaminants. 


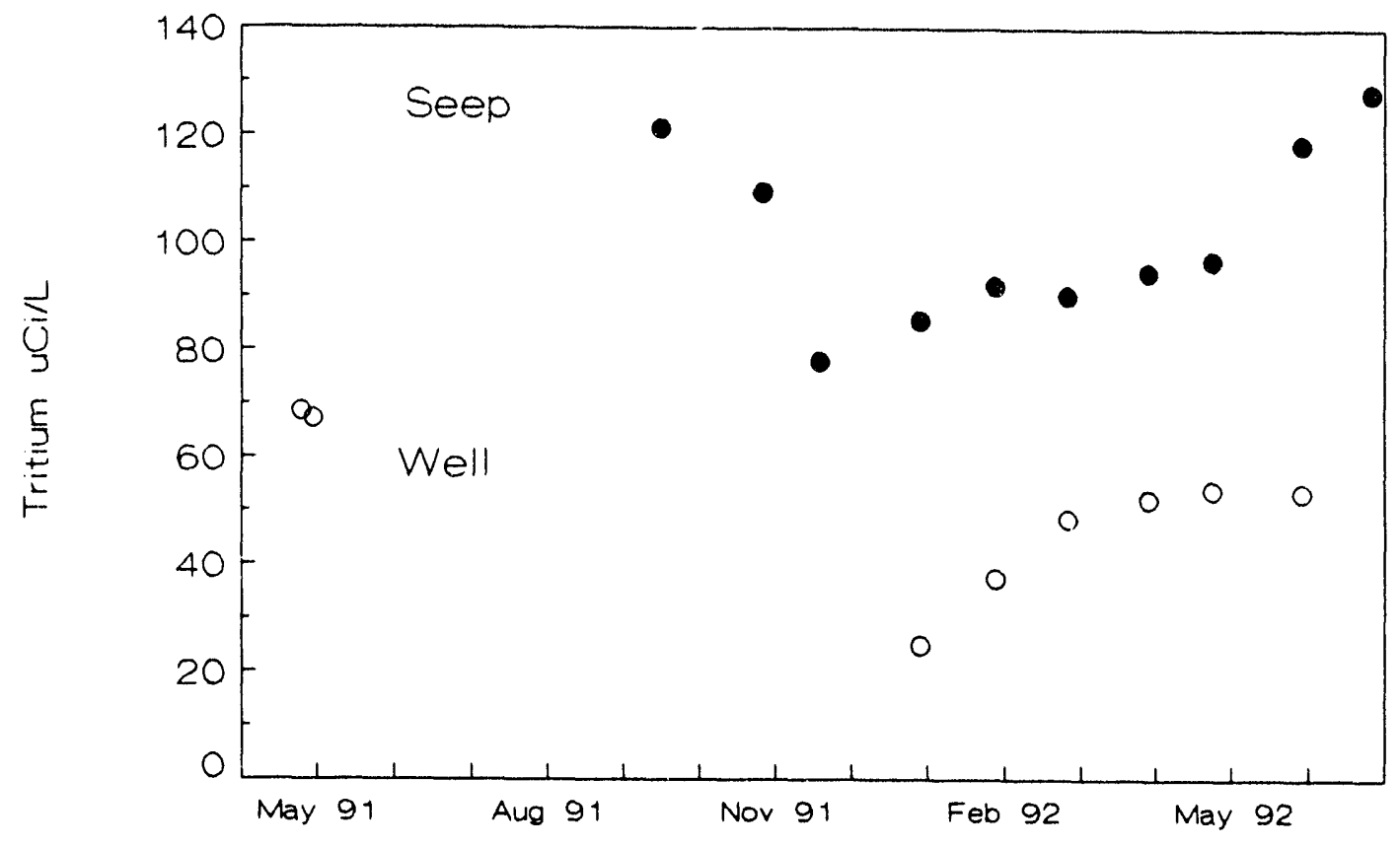

Fig. 20. Temporal activity of ${ }^{3} \mathrm{H}$ in the seep and Well 5D.

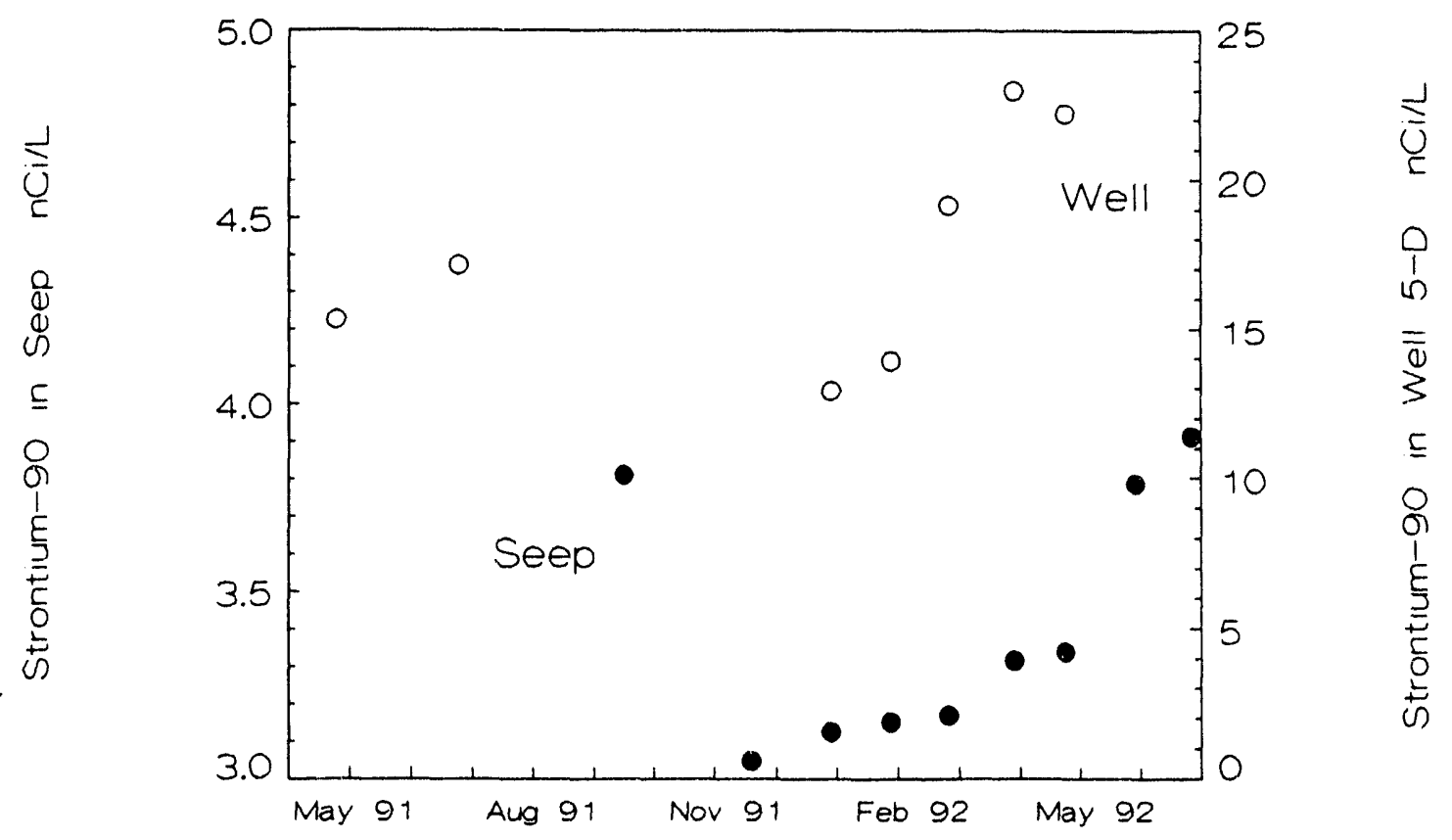

Fig. 21. Temporal activity of ${ }^{90} \mathrm{Sr}$ in the seep and Well 5D. 


\section{SUMMARY}

As a continuation of an investigation aimed at understanding subsurface transport, determining contaminant sources, and aiding remediation decisions, the work completed in 1992 consisted of determining groundwater flow zones in an area of SWSA 5 where a known contaminant plume (primarily ${ }^{3} \mathrm{H}$ ) exists. Locating groundwater flow zones (permeable pathways) and relating them to contaminant activities in the surround matrix can provide information about primary and secondary sources.

Two methods were used to determine permeable zones within a 26-ft-deep borehole drilling on the southeastern edge of SWSA 5. The first was a survey of changes in vertical flows over the depth of the borehole, using the electromagnetic (EM) borehole flowmeter developed by Tennessee Valley Authority. The second was the borehole dilution method, which provided estimates of groundwater flow in different packed off intervals within the borehole. The EM borehole flowmeter results suggest that the zone from 15 to $18 \mathrm{ft}$ below land surface is relatively the most permeable in the borehole. The borehole dilution test results correspond well with the flowmeter results and indicate that the highest water-bearing zone is within the intervai 13 to $16.25 \mathrm{ft}$ below land surface. The specific discharge value for this interval determined by the borehole dilution technique was $1.46 \mathrm{ft} / \mathrm{day}(162 \mathrm{~m} / \mathrm{year})$. Specific discharge values in most of the other intervals (above and below 13 to $16.25 \mathrm{ft}$ ) ranged from 0.3 to $0.7 \mathrm{ft} /$ day. Because groundwater streamlines converge towards an open borehole, the true specific discharge in the formation is probably less than these values. Comparisons of independent data (stream discharge and ${ }^{3} \mathrm{H}$ mass flow from a nearby tritiated seep) with the specific discharge values determined by the borehole dilution technique suggest that the values are reasonable and are likely to be within a factor of 4 of the true specific discharge values.

Results from monthly monitoring of a nearby well and seep (where tritiated groundwater discharges) indicate that there is some seasonal variability in the transport of ${ }^{3} \mathrm{H}$ and ${ }^{90} \mathrm{Sr}$ from the study area. Tritium and ${ }^{90} \mathrm{Sr}$ activities varied over the sampling period from April 1991 to June 1992. Variations in hydrologic conditions (seasons) appear to govern both ${ }^{3} \mathrm{H}$ and ${ }^{90} \mathrm{Sr}$ activities in the seep, with activities being lowest during the wetter (winter) season and higher in the late spring and summer when conditions are drier.

In 1991 the vertical distribution of ${ }^{3} \mathrm{H}$ over a sampled interval 0 to $10 \mathrm{ft}$ deep increased with depth $(0.02$ to $279 \mu \mathrm{Ci} / \mathrm{L})$. To gain knowledge of the ${ }^{3} \mathrm{H}$ activities in the formation at greater depths, core samples, primarily shale samples, from the borehole drilling were analyzed for ${ }^{3} \mathrm{H}$. The results suggest that the activity generally decreases with depth below $10 \mathrm{ft}$; however, because of the drilling method, these results are tentative. As the study continues in 1993, reliable ${ }^{3} \mathrm{H}$ and ${ }^{90} \mathrm{Sr}$ activities will be determined at depth in the different subsurface zones by using a multilevel sampling device installed in the borehole. This will provide the information needed to better understand the subsurface transport and sources of ${ }^{3} \mathrm{H}$ in this area of SWSA 5. By comparing the ${ }^{3} \mathrm{H}$ activity in the most permeable pathway with the ${ }^{3} \mathrm{H}$ activity in the matrix, the relative contributions of primary and secondary contaminant sources to the contaminant release from this area of SWSA 5 can be determined, thus aiding the proper selection and evaluation of remedial actions. 


\section{REFERENCES}

Drost, W., D. Klotz, A. Koch, H. Moser, F. Neumaier, and W. Rauert. 1968. Point dilution methods of investigating groundwater flow by means of radioisotopes. Water Resources Res. 4:125-146.

EPA (Environmental Protection Agency). 1980. Prescribed procedures for measurement of radioactivity in drinking water. EPA-600/4-80-032, pp. 75-82.

Halevy, E., H. Moser, O. Zellhofer, and A. Zuber. 1967. Borehole dilution techniques: a critical review. Isotopes in Hydrology. IAEA, Vienna, pp. 531-564.

Larsen, I. L. 1981. Strontium-90 determinations by Cerenkov radiation counting for well monitoring at Oak Ridge National Laboratory. ORNL/TM-7760. Environmental Sciences Division Publication No. 1701. Oak Ridge National Laboratory.

Moore, G. K., and S. C. Young. 1992. Indentification of groundwater-producing fractures by using an electromagnetic borehole flowmeter in monitoring wells on the Oak Ridge Reservation, Oak Ridge, Tennessee. ORNL/ER-91. Oak Ridge National Laboratory.

Ross, H. H. 1969. Measurement of beta-emitting nuclides using Cerenkov radiation. Anal. Chem. 41:1260-1265.

Solomon, D. K., J. D. Marsh, I. L. Larsen, D. S. Wickliff, and R. B. Clapp. 1991. Transport of contaminants during storms in the White Oak Creek and Melton Branch Watersheds. ORNL/TM-11360. Environmental Sciences Division Publication No. 3395. Oak Ridge National Laboratory.

Wickliff, D. S., D. K. Solomon, and N. D. Farrow. 1991. Preliminary investigation of processes that affect source term identification. ORNL/ER-59. Oak Ridge National Laboratory.

Young, S. C., H. S. Pearson, G. K. Moore, and R. B. Clapp. 1991. Application of the electromagnetic borehole flowmeter technique at the Oak Ridge National Laboratory. WR28-1-900-247. Tennessee Valley Authority. 


\section{DISTRIBUTION}

ORNL/ER-154

$\begin{aligned} 1 . & \text { T. L. Ashwood } \\ 2 . & \text { F. P. Baxter } \\ 3 . & \text { L. D. Bates } \\ 4 . & \text { D. T. Bell } \\ 5 . & \text { D. M. Borders } \\ 6 . & \text { H. L. Boston } \\ 7 . & \text { J. B. Cannon } \\ 8-9 . & \text { R. B. Clapp } \\ 10 . & \text { J. H. Cushman } \\ 11 . & \text { M. F. P. DeLozier } \\ 12 . & \text { R. B. Dreier } \\ 13 . & \text { T. O. Early } \\ 14 . & \text { N. D. Farrow } \\ 15 . & \text { T. A. Fontaine } \\ 16 . & \text { D. E. Fowler } \\ 17 . & \text { S. B. Garland } \\ 18 . & \text { C. W. Gehrs } \\ 19 . & \text { C. D. Goins } \\ 20 . & \text { S. M. Gregory } \\ 21 . & \text { P. J. Halsey } \\ 22-27 . & \text { D. S. Hicks } \\ 28 . & \text { S. G. Hildebrand } \\ 29 . & \text { D. D. Huff } \\ 30 . & \text { P. M. Jardine } \\ 31 . & \text { P. Kanciruk } \\ 32 . & \text { R. H. Ketelle }\end{aligned}$

\author{
33. B. L. Kimmel \\ 34-36. D. M. Matteo \\ 37. G. K. Moore \\ 38-39. P. T. Owen \\ 40. D. E. Reichle \\ 41. G. E. Rymer \\ 42. P. A. Schrandt \\ 43. F. E. Sharples \\ 44. L. A. Shevenell \\ 45. D. S. Shriner \\ 46-51. D. K. Solomon \\ 52. S. H. Stow \\ 53. M. F. Tardiff \\ 54. L. E. Toran \\ 55. J. R. Trabalka \\ 56. R. I. Van Hook \\ 57. D. R. Watkins \\ 58. O. R. West \\ 59. R. K. White \\ 60. Central Research Library \\ 61-63. ESD Library \\ 64-68. ER Document Management Center \\ 69-70. ORNL Laboratory Records Dept. \\ 71. ORNL Patent Section \\ 72. ORNL Y-12 Technical Library
}

73. Office of Assistant Manager for Energy Research and Development, DOE Oak Ridge Field Office, P.O. Box 2001, Oak Ridge, TN 37831-8600

74. J. F. Franklin, Bloedel Professor of Ecosystem Analysis, College of Forest Resources, University of Washington, Anderson Hall AR-10, Seattle, WA 98195

75. R. C. Harriss, Institute for the Study of Earth, Oceans, and Space, Science and Engineering Research Building, University of New Hampshire, Durham, NH 03824

76. G. Y. Jordy, Director, Office of Program Analysis, Office of Energy Research, ER-30, G-226, U.S. Department of Energy, Washington, DC 20545

77-78. R. L. Nace, Branch Chief, Nonenrichment Facilities, Oak Ridge Program Division, Office of Eastern Area Programs, Office of Environmental Restoration, EM-423, Trevion 2, U.S. Department of Energy, Washington, DC 20585

79. R. H. Olsen, Professor, Microbiology and Immunology Department, University of Michigan, Medical Sciences II, \#5605, 1301 East Catherine Street, Ann Arbor, MI 48109-0620

80. A. Patrinos, Director, Environmental Sciences Division, Office of Health and Environmental Research, Office of Energy Research, ER-74, U.S. Department of Energy, Washington, DC 20585

81-82. R. C. Sleeman, DOE Oak Ridge Field Office, P.O. Box 2001, Oak Ridge, TN 37831-8541

83-84. J. T. Sweeney, DOE Oak Ridge Field Office, P.O. Box 2001, Oak Ridge, TN 37831-8541

85. D. W. Swindle, Radian Corporation, 120 South Jefferson Circle, Oak Ridge, TN 37830 
86-87. H. M. Thron, Chief, Enrichment Facilities, Oak Ridge Program Division, Office of Eastern Area Programs, Office of Environmental Restoration, EM-423, Trevion 2, U.S. Department of Energy, Washington, DC 20585

88. F. J. Wobber, Environmental Sciences Division, Office of Health and Environmental Research, Office of Energy Research, ER-74, U.S. Department of Energy, Washington, DC 20585

89-90. Office of Scientific and Technical Information, P.O. Box 62, Oak Ridge, TN 37831 


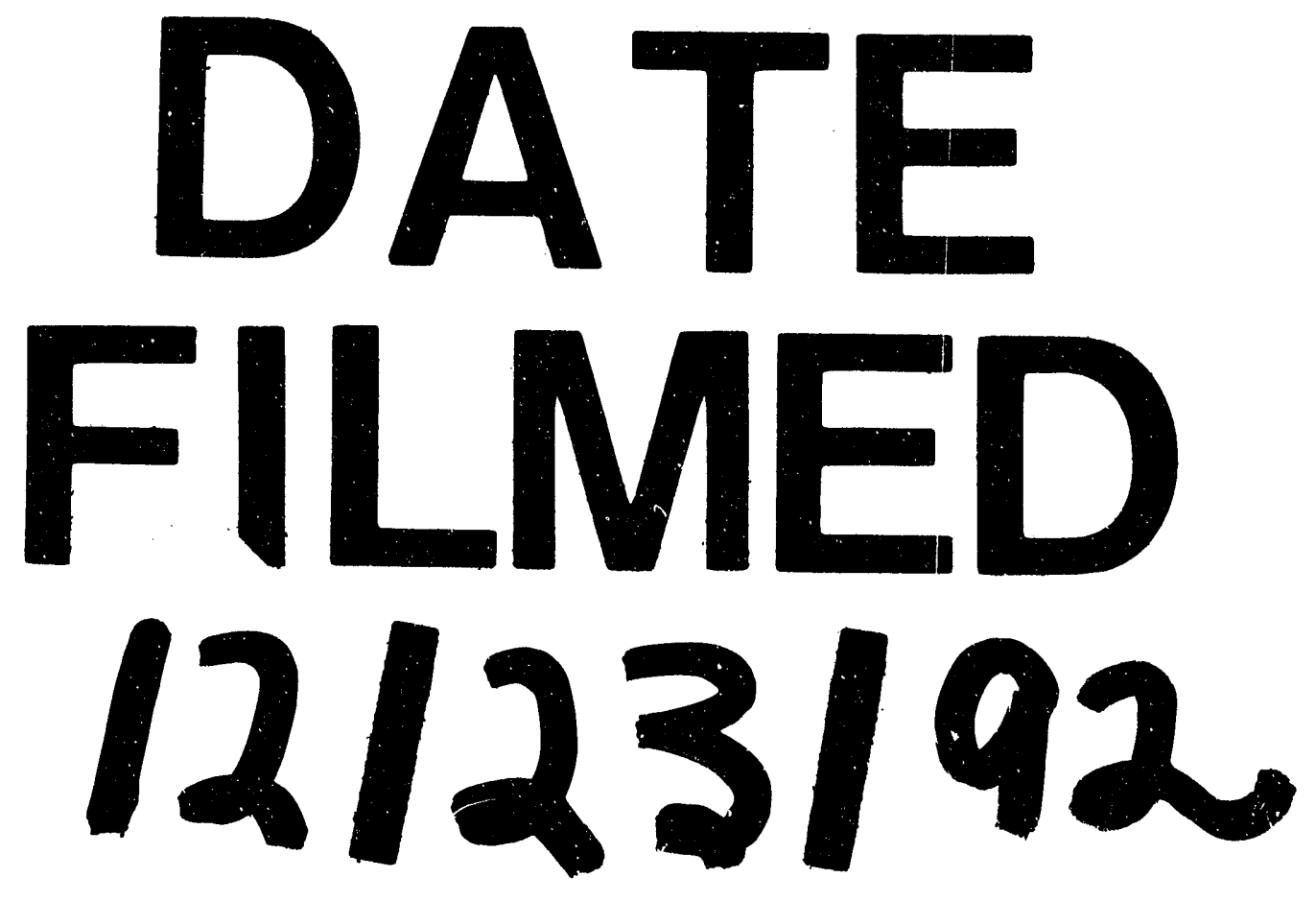


